\title{
"Eu quero sair, eu quero curtir, eu quero ser eu": memórias de velhos e velhas dissidentes
}

\author{
Marcos Tolentino* \\ ORCID iD 0000-0002-0977-397X \\ Acervo Bajubá, São Paulo, Brasil \\ Yuri Fraccaroli* \\ ORCID iD 0000-0001-5405-8054 \\ Acervo Bajubá, São Paulo, Brasil
}

Resumo: Recentemente, as velhices de lésbicas, gays, bissexuais, travestis, transexuais, transgêneros, queer, intersexuais, assexuais entre outros dissidentes (LGBTQIA+) vêm adquirindo maior visibilidade, e, com isso, recebendo atenção da sociedade civil. Em paralelo, é possível observar também um atual contexto de empreendimentos pela memória política de pessoas LGBTQIA+, que buscam recuperar as histórias e as memórias desses agentes, sobretudo, no contexto de resistência e repressão da ditadura civil-militar brasileira. Tomando como ponto de partida este duplo contexto, composto tanto pela emergência desses agentes como velhos LGBTQIA+, quanto pela interpelação deles e delas como testemunhas políticas da ditadura, este artigo busca indagar o lugar de agência nesses testemunhos. Para tanto, operamos uma análise dos testemunhos produzidos pelo Museu da Diversidade Sexual (MDS) de São Paulo, no marco do programa "Memórias da Diversidade Sexual".

Palavras-chave: Testemunho. LGBTQIA+. Velhices. Memória social.

\section{“I want to go out, I wanna enjoy, I wanna be me": elders' dissident memories}

Abstract: The aging of lesbians, gays, bisexuals, transvestites, transexuals, transgenders, queers, intersexuals, asexuals and more (LGBTQIA+) has been gaining recently greater visibility, and with this

Mestre e doutorando em História pela Universidade Estadual de Campinas (Unicamp), com orientação do Prof. Dr. José Alves de Freitas Neto. E-mail: marcosoat@hotmail.com.

* Mestre em Psicologia Social pela Universidade de São Paulo (USP), com orientação do Prof. Dr. Bernardo Parodi Svartman. E-mail: yurifraccaroli@gmail.com. 
receiving greater attention from civil society. In parallel, it is also possible to observe the current context of memory recovery initiatives related with LGBTQIA+ people's experiences during the brazilian civilmilitary dictatorship. Considering this double context of emergence of these agents as LGBTQIA+ elders and the interpolation of their memories about the dictatorship, this article seeks to investigate the narrative agency in their testimonies. To this end, we analyze the testimonies produced by the Museum of Sexual Diversity (MDS) of São Paulo, within the "Memories of Sexual Diversity" program.

Keywords: Testimony. LGBTQIA+. Aging. Social memory.

No prefácio de sua última obra, intitulada Velhice transviada (2019), por meio de poemas, dados e algumas memórias, o escritor e psicólogo João W. Nery elabora o que significa envelhecer como pessoa trans ${ }^{1}$ no Brasil. Este pequeno texto traz um pouco da multiplicidade de experiências e compreensóes do processo de envelhecer para as pessoas trans, reconhecendo, por exemplo, as particularidades entre ser um transvelho e ser uma transvelha, e destacando também as gritantes diferenças entre o envelhecer das pessoas cisgêneras em relação às pessoas transidosas - condição que, inclusive, a grande maioria das pessoas trans e travestis não chega a vivenciar em razão das mais diversas violências às quais são expostas durante a vida (Nery, 2019, p. 11-17). ${ }^{2}$

Entretanto, em direção à conclusão, Nery se reporta à fala de um amigo de 56 anos, que havia transicionado onze anos antes, que aponta outro sentido à experiência do envelhecimento: "Hoje me sinto mais jovem do que nunca, João, com uma disposição que náo tinha aos trinta, quando ainda vivia dentro do armário, em depressáo. Faço academia, namoro bastante e transo numa boa. Voltei a estudar e nunca fui tão feliz. Nem pensar em falar de velhice" (Nery, 2019, p. 15). Essa fala nos chama atenção especialmente por dois motivos, pelos quais gostaríamos de iniciar a discussáo do presente artigo.

Em primeiro lugar, é interessante notar como a agência narrativa expressada pelo amigo de Joâo compreende positivamente sua etapa de vida, o que irrompe de forma inesperada na linha de sequência do prefácio, que até entáo trazia apenas os aspectos da violência sofrida pelos chamados transidosos. Nesse sentido, trabalhos recentes,

1 Neste artigo, utilizamos a expressão "trans" como referência às identidades de gênero não conformes à cisgeneridade, sendo que esta pode ser resumida como "sendo a identidade de gênero daquelas pessoas cuja 'experiência interna e individual do gênero' corresponda ao 'sexo atribuído no nascimento' a elas" (Vergueiro, 2015, p. 45). Debaixo dessa multiplicidade de expressões e identidades não cisgêneras, podese citar, como exemplo, as identidades transexuais, transgêneras, travestis, queer, entre outras.

2 No Dossiê "Assassinato e Violência contra Travestis e Transexuais Brasileiras em 2020", lançado em janeiro de 2021, a Associação Nacional de Travestis e Transexuais do Brasil (ANTRA) aponta para a ausência de dados governamentais sobre a população de travestis e transexuais. Esse dossiê, lançado anualmente pela ANTRA no Mês da Visibilidade Trans, é uma das poucas iniciativas de caráter nacional de sistematização de dados sobre essa parcela da população. Ver: Benevides et al. (2021). 
sobretudo, no campo da Antropologia Cultural e Social (Simóes, 2011; Passamani, 2015; Henning, 2017), vêm apresentando outras possibilidades de ser/estar/viver gênero e sexualidades dissidentes na velhice a partir de modos que não necessariamente passam pela marginalização, pelo trauma, pela estigmatização ou pelo sofrimento; marcos que, como veremos, têm sido centrais nos recentes agenciamentos da memória política $^{3}$ dos sujeitos e práticas dissidentes à cisheteronormatividade. ${ }^{4}$

É também por esse caminho que se constroem outras compreensões sobre as velhices, tensionando conceitos que recorrentemente adotam de forma pouco refletida eixos heteronormativos para abordá-la, de modo análogo às inflexóes feministas que Guita Debert provocou nos anos 1970 ao pensar o que poderia ser o envelhecimento para as mulheres:

Quando se pensava na velhice, a referência era a experiência masculina: a passagem do mundo público, com a aposentadoria, para o mundo privado. Outro fator que revelava o drama da velhice para os homens era a perda da vida sexual ativa. Tradicionalmente, as mulheres ficavam restritas à esfera doméstica e, como mostravam os estudos, não tinham sua sexualidade realizada. Entáo, qual o significado da velhice para elas? (Torres; Debert, 2011, p. 3, grifos nossos).

Para que possamos, portanto, pensar no plural, ou seja, em velhices dos sujeitos dissidentes, considerando tanto os modos de existência que se identificam com a contemporânea e cambiante sigla LGBTQIA $+{ }^{5}$ quanto aqueles não identitários (Peres; Toledo, 2011) e/ou que se identificam a partir de outros referenciais e contextos, a reflexão do primeiro motivo nos conduz ao entendimento de que, frente à recente visibilidade do tema, sejam reconhecidas as experiências daquelas e daqueles que a vivenciam, tornando-se urgente um cuidado metodológico que náo traga "nossos interlocutores como coisa pensada" (Gonçalves Filho, 2003) e que, pelo contrário, permita suas agências narrativas. ${ }^{6}$ Essa atenciosa escuta é estratégica quando consideramos a inexistência de dados e políticas públicas para este segmento populacional e sua importância para a articulação e reivindicação pela promoção e garantia dos direitos humanos (Henning, 2017).

Já em relação ao segundo motivo, este surge da percepção de que, quando o amigo

3 Sobre o conceito de agenciamento de memória política, consultar: Lifschitz (2014).

4 Em consonância com Butler (2015), compreendemos que essa normatividade se fundamenta em especial na ficcional linearidade entre sexo, gênero e desejo.

5 Sobre a discussão a respeito da sigla que engloba lésbicas, gays, bissexuais, travestis, transexuais, transgeneros, queers, intersexuais e outras identidades de gênero e orientações sexuais, recomendamos as discussões de Facchini (2012, p. 133-134), em especial, sobre o "campo" e a "arena" do movimento social.

6 Entre outras preocupações e aspectos presentificados nesses exercícios intertemporais, ressaltamos em especial o cuidado em utilizar entendimentos identitários e políticos do presente, como, por exemplo, 
de Nery afirma "nem pensar em falar de velhice", encontramos aí um reconhecimento que opera uma significação social da velhice como algo negativo. Este aspecto, segundo Goldenberg $(2013,2018)$, seria um traço marcante da cultura brasileira, que significa a juventude e o corpo jovem como valores positivos e desejáveis, em especial no que se refere aos corpos femininos. Em outras palavras, tratar-se-ia de uma situação vivenciada não apenas pelos sujeitos dissidentes; e aqui resulta necessário considerar que além de dissidentes ao sistema de sexo e gênero, esses agentes são também atravessados por outros marcadores sociais da diferença, entre eles, raça, classe social e etarismo, invisibilizados se os consideramos apenas a partir do eixo sexo-gênero.

Assim, entendemos que, para as tentativas de compreender o fenômeno do envelhecimento desses sujeitos, o desafio que se apresenta é duplamente composto: como indagar o plural reconhecimento das singularidades de vivenciar e narrar as velhices das/dos dissidentes para além da marginalização, da violência e do estigma, sem com isso negligenciarmos a operação de aspectos estruturais e marcos coletivamente compartilhados em tais vivências e narrativas? E além disso, como operarmos tais exercícios de escuta sem incorrer necessariamente em sobrecodificaçoóes ${ }^{7}$ das experiências e identidades relatadas, ou seja, pensarmos sem as devidas problematizaçóes essas experiências sexo-gênero dissidentes a partir de leituras, compreensôes e identidades políticas ancoradas no presente?

Certamente, não temos a pretensão de resolver esse impasse. Entretanto, no presente artigo, intencionamos ao menos pensar sobre essas questôes a partir da mesma operação pela qual iniciamos nossa reflexáo: concedendo primazia aos testemunhos. Para tanto, analisaremos os testemunhos produzidos no marco da websérie "Memórias da Diversidade Sexual", uma iniciativa do Museu da Diversidade Sexual (MDS) ${ }^{8}$ realizada em parceria com o diretor Lufe Steffen. Lançada em 28 de junho de 2018, no "Dia Internacional do Orgulho LGBT", esse programa teve como objetivo "apresentar os depoimentos de pessoas LGBTI acima dos 65 anos, residentes na cidade de São

LGBTQIA+ para indagar experiências do passado ou adotar categorias supostamente universais como "homossexualidade" para se referir hegemonicamente à totalidade de expressões e identidades de um período, como problematicamente ocorrido no bojo das discussões da Comissão Nacional da Verdade (CNV).

7 Sobre o conceito de sobrecodificação, proposto por Félix Guattari, adotamos a interpretação do antropólogo Vitor Grunvald (2016, p. 80), para quem, além da codificação ou atribuição de um sentido, deve ser salientada "a garantia (persuasão) de uma codificação específica; ou, em outras palavras, o instrumento através do qual se determina esse e não outro sentido, essa e não outra relação entre os termos. O estabelecimento, portanto, de uma codificação para o processo de codificação, daí uma sobrecodificação: o desejo que os termos funcionem de uma determinada maneira na atribuição de significados mútuos; e a necessidade que exista uma relação unívoca e bastante familiar entre eles".

8 O MDS é um equipamento estatal de cultura criado em 2012 pela Secretaria da Cultura do Estado de São Paulo para a salvaguarda do "patrimônio social, político e cultural da comunidade LGBTQIA+ brasileira", em especial a paulista; e para "valorizar" e "visibilizar" a diversidade sexual e a sua "importância" para a "construção social, econômica e cultural do Estado de São Paulo e do Brasil". 
Paulo que contam suas experiências de infância, adolescência e velhice na cidade, como repressão, relação com a família, com a noite e militância". As dez entrevistas foram divididas em cinquenta capítulos temáticos e, ao longo de um ano, foram lançadas semanalmente no canal do YouTube do MDS, constituindo na plataforma de compartilhamento de vídeos um acervo de História Oral de consulta pública e gratuita. ${ }^{9}$

Como afirmam Michael Pollak e Natalie Heinich, a prática do testemunho não depende apenas da vontade ou da capacidade de potenciais testemunhas de reconstruir sua experiência: ela se baseia principalmente nas condiçóes sociais que tornam o seu relato comunicável (Pollak; Heinich, 2006). Desse modo, faz-se mister observar que para que esses testemunhos fossem produzidos e disponibilizados em formato audiovisual, houve o interesse e o investimento, além da existência de um equipamento estatal voltado para a preservaçáo das memórias da "comunidade LGBTQIA+ brasileira", como o próprio museu define. Entretanto, em nosso entendimento, é preciso certa cautela e reconhecer que esta realidade é parte de um processo mais amplo de configuraçáo de uma demanda social para que a experiência dos sujeitos dissidentes fosse objeto de indagação e de reconhecimento, superando lógicas de "silêncio" e garantindo a emergência de suas "memórias subterrâneas" (Pollak, 1989). Nesse sentido, conforme será abordado, as preocupaçóes com as memórias dos sujeitos dissidentes já se faziam presentes, por exemplo, no início do entáo Movimento Homossexual Brasil (MHB) e expressados também na chamada imprensa alternativa, como o jornal Lampião da Esquina (1978-1981).

Em síntese, longe de desconsiderar a relevância do museu na produção desses testemunhos, o que se busca frisar é parte das condiçóes políticas e sociais que possibilitaram a constituição do MDS como um equipamento cultural que tem como propósito um "dever de memória" frente ao constante apagamento das histórias e memórias dos sujeitos dissidentes. Isso nos leva a considerar também as possíveis influências dessas condições no seu modo de operar, isto é, por meio da articulação da

As atividades desenvolvidas pelo MDS incluem a coleta, organização e disponibilização pública de referenciais materiais e imateriais; a constituição de um Centro de Memória e Pesquisa; a produção de exposições temporárias na sede do museu, temporariamente na estação do metrô República, centro de São Paulo; e atividades educativas e de mediação cultural. Para informações sobre o Museu da Diversidade Sexual (MDS), ver: http://www.mds.org.br/quem-somos/ Acesso em: 8 fev. 2020

9 Entre as pessoas entrevistadas estão: Carlos Capelletti, Marisa Fernandes, Eloína dos Leopardos, Lili Vargas, Edy Estar, Marise Louvison, Miss Biá, Glauco Mattoso, e os casais: César Gioggi e Paulo Mortari, e Paulo Montoro e Kelley White. Para informações sobre o lançamento do programa "Memórias da Diversidade Sexual”, ver o post do perfil do MDS na rede social Instagram (@museudadiversidadesexual), de 28 junho de 2018. Disponível em: https://www.instagram.com/p/BklC-ZyB2d_/. Acesso em: 8 fev. 2020. 
memória com o paradigma dos direitos humanos. ${ }^{10}$ Essa articulaçáo, como aponta em seu site, relaciona-se a um entendimento da valorização da memória como estratégia de enfrentamento à discriminação e à violência que resultaram no "cerceamento dos seus direitos" e na "invisibilidade" da "comunidade LGBTQIA+ brasileira".

Além do espaço, a data escolhida para o seu lançamento buscou também legitimar um caminho para a emergência e a circulação pública dos relatos: 28 de junho, um "núcleo convocatório" para as militâncias LGBTQIA+ no Brasil e no mundo (Stern, 2006). Nesse dia, as questôes relacionadas com as pessoas LGBTQIA+ tornam-se pautas da agenda pública, o que inclui alguns processos memorialísticos relacionados às histórias das comunidades LGBTQIA+ e o seu histórico de luta pelo reconhecimento de direitos.

Percebe-se, portanto, que essa "busca" de histórias e memórias usualmente parte das condiçóes do presente de pessoas que se entendem como LGBTQIA+ e/ou de instituiçōes voltadas a essa comunidade, como o MDS, articula leituras do passado com claros objetivos sociais e políticos. Não pretendemos com isso postular a possibilidade de operar uma história neutra, nem desabonar essas narrativas e interpretaçôes do passado. Buscamos apenas refletir criticamente sobre seus usos, sem naturaliza-los, considerando suas inclusóes, mas reconhecendo também possíveis exclusôes:

Se o olhar ao passado permeado pela busca do reconhecimento político é sem dúvidas importante, deve-se atentar aos limites das representações imbuídas em seus empreendimentos. Consonante a Butler (2003), faz-se mister pensar que cada inclusão é sempre acompanhada de certas exclusóes e que, por vezes, aspectos deveras mais relevantes que incidem sobre a exclusão não são refletidos, como, por exemplo, a estrutura ou o próprio ato/cena de reconhecimento. Quais são os limites das histórias que temos contado? Quais sujeitos estão sendo incluídos? Quem tem definido essas representaçóes? Não podemos estar operando exclusóes que poderiam ser minimizadas a partir de outras práticas de memória? Isso serve para pensarmos tanto nos aspectos que ressaltamos como dignos de serem relembrados, quanto a certa ênfase na relação com o Estado como cena principal de reconhecimento. (Fraccaroli, 2019, p. 22).

Nesses termos, o que significa interpelar o passado a partir da categoria "homossexualidades", como fez a Comissão Nacional da Verdade (CNV)? Ou o que pode vir a significar uma memória viada? Isso incluiria as memórias de sapatóes? É possível falarmos em uma memória LGBTQIA+, quando pensamos que muitos

10 Por limitações de espaço, não nos estenderemos sobre este tema, mas recomendamos a leitura de Facchini e Simões (2009), para refletir sobre as mudanças nos anos 1980 do então movimento homossexual com a redemocratização e a constituinte como chaves para pensar essa retórica de luta por direitos políticos e sociais e os desdobramentos dessa configuração no ativismo durante a década de 1990 - sem desconsiderar, certamente, o papel da epidemia de HIV/AIDS nesses processos. 
dos sujeitos que são interpelados por esses dispositivos de memória nem sequer se identificavam no passado ou se reconhecem no presente a partir dessa sopa de letrinhas (Facchini, 2005, 2012)?

Tomando emprestada as reflexóes iniciais de Ricoeur (2007), quando propóe o estudo da memória a partir de uma análise fenomenológica centrada nos questionamentos "memória de quê" e "memória de quem", talvez possamos operar certas delimitaçóes conceituais que busquem evitar exclusôes ou sobrecodificaçôes das experiências e produçôes identitárias. Nesse sentido, falar em uma memória LGBTQIA+ pode ter seu sentido quando consideramos que os movimentos de memória partem do presente e estáo, portanto, condicionados às articulaçóes políticas e ao contexto social contemporâneo. Ou seja, ainda que parte dos sujeitos possam ou não se reconhecer como LGBTQIA+, seu testemunho é indagado por dispositivos que operam a partir dessas identificaçôes e possíveis diferenças podem ser percebidas a partir desse encontro intertemporal, o que nos leva também a questionar o "quê" da memória - o que é lembrado. E nesse conteúdo lembrado, referente ao passado, por muitas vezes essa sigla e os entendimentos do presente acabam por se desvanecer ou tensionar as próprias categorias do presente.

Desse modo, optamos pela ideia de "memórias LGBTQIA+" ou "memórias de LGBTQIA+", quando a ênfase está no processo do presente e ancorado no "quem" da memória, de onde parte; e para nos referirmos aos diversos movimentos por memórias das dissidências sexuais e de gênero, considerando aqueles aspectos que podem haver em comum, mas também as diferenças nesses processos e cientes dos riscos inerentes a qualquer pretensão identitária universalista, utilizamos os termos "memórias dissidentes" ou "memórias das dissidências". ${ }^{11}$ Com esta proposta, além de buscar diminuir equívocos, supressóes e apagamentos do passado, acreditamos equilibrar um olhar atento e que legitime as condiçóes do presente, uma vez que se encontramos "memórias da dissidência", essas em geral partem de exercícios de "memórias de LGBTQIA+".

Pensando nessas e em outras questóes, a partir de uma perspectiva situada (Haraway, 1995), buscamos, portanto, por meio da escuta contextualizada dos testemunhos, aproximarmo-nos dos sentidos expressados pelos entrevistados em relaçáo (i) às suas experiências pessoais e coletivas rememoradas e (ii) às compreensôes sobre as velhices e suas identidades produzidas nos relatos. Devido à recente visibilidade que este recorte desperta e aos efeitos da própria dissidência ao sistema sexo-gênero nos processos de envelhecer, vivenciar e compreender o envelhecimento, é preciso considerar (iii) que esses testemunhos podem constituir outras temporalidades (Henning, 2016) e adotar outros pontos de ancoragem de memórias, fugindo de lugares e instituições

Mais comentários sobre essas relações são tecidos na próxima seção do artigo. 
privilegiadas pela heterossexualidade compulsória (Rich, 2012) - como a família, o casamento e/ou o trabalho -, mas também dos próprios marcos e entendimentos identitários adotados por alguns dos atuais empreendimentos de história/memória política de LGBTQIA+.

De modo geral, percebe-se certa ênfase nas experiências ocorridas durante o período da ditadura civil-militar (1964-1985), com especial atençáo às narrativas de exintegrantes dos primeiros grupos de militância, e a operação de um binômio constituído pelos termos "repressão/resistência", que é utilizado para a compreensão e significação desse passado histórico no marco das questóes do presente: vítimas da repressão ditatorial ou resistentes ao autoritarismo e ao cerceamento das liberdades. Tratar-se-iam de certos enquadramentos de memória que nos conduzem a reflexōes sobre a própria ética nessas indagaçóes do passado a partir de situaçóes de precariedade ${ }^{12}$ no presente. Como expressa Sônia Sissy Kelly Lopes ao ser questionada se pensaria no futuro: "O futuro de uma travesti é hoje. Amanhã não se sabe e nem se quer pensar" (Nery, 2019, p. 146). Essa constatação desenha a espinhosa localização de nossa reflexão: como pensar eticamente esse "dever de memória" quando nem mesmo os espaços do presente e do futuro de quem narra são respeitados?

Em diálogo com Sissy, entendemos que o narrar e o viver podem se aproximar ao reconhecermos a visibilidade que as memórias do passado podem aportar para o presente, superando um constante apagamento, e construindo assim um outro horizonte de espera, como afirma Ecléa Bosi (2013, p. 67): "O tempo da lembrança não é o passado, mas o futuro do passado [...] o limite para o qual tende a memória narrativa é a transição da nostalgia para um 'horizonte de espera', na feliz expressáo de Paul Ricoeur". Torna-se imprescindível, portanto, reconhecer não apenas os processos e significaçóes dos envelhecimentos das e dos dissidentes, mas antes disso, reconhecer a própria vida daquele ou daquela que envelhece e narra, posto que essas vivências condicionam também as condições de possibilidade de se envelhecer ou não dignamente:

[...] ao buscarem a visibilidade de seu reconhecimento por meio da transmissão da memória, superando um constante apagamento, podem influenciar nas possibilidades de vivenciar o sexo e o gênero. Aqui vale o argumento de Sócrates, quem entende que apenas uma vida possível de ser analisada seria uma vida digna de ser vivida, ou seja, humana. (Fraccaroli, 2019, p. 59).

Logo, o presente artigo se estrutura em quatro partes: (i) na primeira, situamos

12 Empregamos o conceito com o sentido de demarcar a existência de grupos que sofrem de uma condição de precariedade politicamente induzida (Butler, 2018, p. 40), expostas, portanto, a um maior risco de “doenças, pobreza, fome, remoção e vulnerabilidade à violência sem proteção do Estado" (Butler, 2018, p. 41). 
histórica e politicamente algumas das condições que permitiram a emergência dessas memórias subterrâneas e dissidentes, estabelecendo as bases conceituais e metodológicas para a reflexáo que fazemos desde os campos da Memória e da História Oral, para que assim possamos pensar criticamente o projeto "Memórias da Diversidade Sexual" e, como conclusão dessa seçáo, apresentando o modo pelo qual lidamos metodologicamente com os testemunhos; (ii) de acordo com os critérios estabelecidos na seção anterior, procuramos analisar a agência narrativa expressada pelos depoentes e suas interlocuçóes ou não com os marcos da memória política produzida por sujeitos dissidentes, problematizando o binômio repressão e resistência e as interpelações destes sentidos compartilhados à iniciativa analisada; (iii) na terceira parte, tratamos de compreender as diferentes significaçóes ao envelhecer produzidas; e conduzindo para a conclusão (iv), refletimos paralelamente sobre os exercícios de memória que visam a dignidade de pessoas LGBTQIA+ no presente e como eles podem ser articulados com perspectivas políticas que busquem o reconhecimento desses plurais modos de se envelhecer e também de narrar a própria vida.

\section{Processos de emergência de memórias dissidentes}

É difícil negar que os últimos anos têm sido marcados pela emergência de memórias de pessoas LGBTQIA+. Para ilustrar essa situação, bastaria lembrar que, no início de 2021, mesmo no contexto da pandemia de covid-19, em São Paulo, já se podia visitar as exposiçóes "Orgulho e Resistências: LGBT na Ditadura" (Memorial da Resistência de Sáo Paulo) e "Madalena Schwartz: As Metamorfoses - Travestis e transformistas na São Paulo dos anos 70" (Instituto Moreira Salles). Essas duas iniciativas sáo apenas alguns exemplos recentes de um movimento mais amplo de processos de emergência de memórias dissidentes, que buscamos recompor parcialmente nesta seção. Entretanto, antes de elaborarmos um esboço das condiçóes e de alguns dos processos que configuraram a emergência dessas "memórias subterrâneas", que viabilizaram em grande parte a produçáo de testemunhos como aqueles do MDS, resulta necessário tecer algumas observaçóes e operar certas delimitaçóes metodológico-conceituais.

Primeiramente, ainda que náo pretendamos com isso fazer uma genealogia ou arqueologia do tema, é importante observar que as preocupaçóes com essas histórias e memórias não seriam uma novidade do presente. Em outros termos, uma vez demarcadas pelas condiçóes sócio-históricas e entendimentos identitários de seus momentos, é possível observar, por exemplo, preocupaçóes com a preservação das memórias do MHB nas atas de reunião do Grupo Outra Coisa, dissidência do grupo SOMOS (Sáo Paulo), que registram algumas ideias de um projeto chamado "Memórias do MHB". ${ }^{13}$

13 Documentação disponível na série 5 - Relatórios de Reunião, do Grupo 1 - Organização e 
Também desde a militância, entretanto já efetivada em prática, encontramos uma convocatória para a formação do Arquivo do Grupo Gay da Bahia (GGB), em 1983, que denuncia a urgência desse dever de memória, podendo ser lida em um dos boletins do grupo:

Temos de guardar nossa memória gay pois infelizmente existe um 'complô do silêncio e de destruiçáo' a tudo que se refere aos homossexuais. O GGB pede insistentemente que os leitores de nosso Boletim nos mandem TUDO que lerem sobre homossexualismo. [...] Queremos coletar também fotos de gays do passado e do presente: mande suas fotos com dedicatória para o 'Arquivo do GGB'. Começamos uma coleção de 'cartas de amor-gay': aceitamos doaçóes de cartas íntimas, diários, etc. (Mott, 2011, p. 124).

Se percebemos usos e sentidos do termo memória relacionado a sujeitos e práticas dissidentes à cisheteronormatividade, considerando as diferentes produçóes identitárias de cada momento histórico, é importante que se determine a que exatamente nos referimos quando utilizamos a expressão "memórias dissidentes", seja conceitualmente ou em termos de localização histórica, reconhecendo sua histórica ênfase política tanto no passado, quanto no presente, com suas potencialidades, mas vislumbrando também possíveis abusos e excessos (Robin, 2016).

Nesse sentido, consideramos as discussóes de Silva (2013, p. 80) no campo da Psicologia Social como um disparador conceitual para essa reflexão. Para o autor, a construção da memória política de pessoas LGBTQIA+ se relacionaria com os processos de identidades coletivas e da formação de uma consciência política. Ainda que tal formulaçáo nos pareça problemática, em especial por estabelecer vínculos com um conceito não situado como o de consciência política, é oportuna à presente discussão ao apontar a urgência de que os movimentos pela construçáo dessas memórias se deem de modo plural, pautados pelo reconhecimento das diferenças e da busca de um permanente estado de reflexáo, efetivando um constante jogo de memória, no qual tornam-se possíveis outras significaçóes da história e a emergência de novos sujeitos nessas narrativas e interpretaçôes.

É nesta arena política, que tenciona presente e passado, e na qual grupos sociais disputam pelos modos de se enquadrar e recordar o passado (Ansara, 2009), que localizamos uma série de iniciativas destinadas a empreender açóes pelas histórias e pelas memórias das dissidências em diversas localidades do território brasileiro. ${ }^{14}$ Desse modo, resulta necessário incorporar à nossa análise a noção de historicidade

Funcionamento do Acervo Outra Coisa, disponível para pesquisa no Arquivo Edgard Leuenroth em Campinas. Consulta ao acervo realizada em fevereiro de 2020.

14 Para um mapeamento de ações em favor da salvaguarda do patrimônio cultural e das memórias LGBTQIA+ pelo Brasil, ver: Baptista e Boita (2017). 
dos testemunhos, pois, como aponta parte significativa da bibliografia sobre Memória e História Oral, as possibilidades de narrar e de escutar mudam com a passagem do tempo (Rousso, 2006).

Ao pensar o testemunho como uma produção ativa de sentidos sobre o passado no presente, visando uma intervenção futura, Elizabeth Jelin propóe que essa historicidade seja pensada a partir da multiplicidade de temporalidades das memórias pessoais, o que nos permite analisar os discursos produzidos relacionando-os com a temporalidade dos processos de produçáo e das diferentes escolhas narrativas dos sujeitos. Nesse sentido, Jelin aponta que os testemunhos, mais do que uma tentativa de reconstrução fiel do passado, trazem em si as marcas do presente em que se narra (clima cultural e político, contexto institucional em que o relato é dado, curso de vida da testemunha, vocabulários disponíveis, etc.); das possibilidades do sujeito/narrador em relatar e silenciar certos aspectos do passado; e dos objetivos, metas e expectativas futuras por trás da produção do seu relato (Jelin, 2017).

Tomando como referência esse embasamento conceitual da prática de testemunho, é possível dialogar com a discussão teórica de Silva (2013), que, ao elencar criticamente as principais dinâmicas psicossociais da memória, e identificar a exclusão dos sujeitos dissidentes da história oficial, reconhece também os riscos da fixidez de uma memória política, mesmo quando contra-hegemônica. Essa articulação é muito relevante quando consideramos os efeitos, por exemplo, na produção de testemunhos agenciados pelo recente empreendimento político Ditadura-Homossexualidades, movimento que resultou na inclusão de um capítulo dedicado à temática no relatório final da Comissão Nacional da Verdade (CNV).

Em síntese, a partir desse quadro conceitual, para que possamos pensar nas possibilidades de agência narrativa, e refletir sobre os traços de subjetividade presentes nos relato, levando em conta as diferentes identidades envolvidas e suas participaçóes diferenciais na partilha desse poder de narrar a si mesmo, desprende-se a importância de localizar brevemente o contexto que envolve a produçấo dos testemunhos do programa "Memórias da Diversidade Sexual". Nesse sentido, interessa-nos questionar: em que contexto temporal e institucional eles foram produzidos (o presente); a quais experiências do passado eles se referem e que permitem pensar as trajetórias dos sujeitos em conjunto (o passado); e como a produção, a circulação e o acesso a esses relatos podem contribuir para possíveis futuros e para o reconhecimento das singularidades e das urgências das experiências de velhice entre as pessoas LGBTQIA+ e demais dissidentes (o futuro).

Em relação ao seu contexto de produção, o projeto "Memórias da Diversidade Sexual" se enquadra em um marco cultural mais amplo de produçáo de narrativas sobre as histórias das dissidências sexuais e de gênero no Brasil e sobre as memórias de LGBTQIA+, um processo que se intensificou na segunda década dos anos 2000, mas que não se trata de um fenômeno político e cultural recente. Nas décadas de 1970 e 
1980, a produção de narrativas históricas e o registro de memórias foi parte do ativismo "homossexual", do surgimento da "história queer" como um campo de reflexão e de pesquisa e dos processos de autorreflexão das próprias comunidades LGBTQIA+ (Rivers, 2012, p. 65). No Brasil, o Grupo Gay da Bahia (GGB), por exemplo, usou os seus boletins informativos, publicados a partir de 1981, como espaço para veicular outras produçóes discursivas e imagéticas que oferecessem principalmente para aqueles leitores que se identificassem como "homossexuais" um conjunto de representaçóes vistas pelo grupo como "positivas", contrapondo-se às imagens pejorativas presentes no imaginário social e materializada pelas representaçóes veiculadas pelos meios de comunicaçáo. Isso se dava por meio de textos sobre episódios que podiam ser lidos como parte de uma "memória LGBTQIA+" (termo que utilizamos desde uma leitura do presente), que reivindicavam, em suas palavras, "gays heroicos na nossa história", ou que demonstraram que as práticas entendidas como "homossexuais" não eram um fenômeno recente (Carneiro, 2017, p. 118-124).

A partir dos anos 2000, iniciativas assim se intensificaram, mas com uma particularidade: elas não eram necessariamente o resultado de práticas ou de discursos militantes, circulando em outros espaços e contextos institucionais. Podemos citar entre as iniciativas que criaram um clima favorável para a emergência e circulaçáo de narrativas históricas e memorialísticas sobre pessoas LGBTQIA+ brasileiras, e que nos permitem pensar nos diversos usos e lugares sociais do testemunho de pessoas LGBTQIA+ (Ricoeur, 2007): a produçáo cultural de filmes de ficção e documentários; ${ }^{15}$ a publicação de livros de memórias e autobiografias; a incorporaçáo de conjuntos documentais sobre as militâncias LGBTQIA+ em arquivos públicos, processo no qual o Arquivo Edgard Leuenroth, na Universidade Estadual de Campinas (AEL/UNICAMP), foi uma das instituiçôes pioneiras; ${ }^{16}$ o surgimento de iniciativas da sociedade civil para a salvaguarda do patrimônio cultural de LGBTQIA+ e outros dissidentes e para a produção de outras narrativas históricas e historiográficas, como, por exemplo, o Acervo Bajubá; ${ }^{17}$ exibiçóes em museus, como, por exemplo, o projeto "Histórias da Sexualidade", do Museu de Arte de São Paulo (MASP), que resultou em

15 Entre os filmes de ficção e documentários, podemos citar, a partir das suas datas de lançamento: Madame Satã (2002); Cazuza - O tempo não pára (2004); Dzi Croquettes (2009); Meu amigo Claudia (2009); ABC Bailão (2010); Flores raras (2013); Tatuagem (2013); Para sempre teu Caio F. (2014); Lampião da Esquina (2016); São Paulo em HI-FI (2016); Divinas divas (20017); Laerte-se (2017); e Cartas para além dos muros (2019).

16 Atualmente, o AEL custodia um dos maiores acervos no país sobre a memória dos movimentos LGBTQIA+ brasileiros. Entre as coleções que integram a temática no AEL, podemos citar: Grupo Somos; Triângulo Rosa; João Mascarenhas; Turma OK; Outra Coisa; Paulo Ottoni; GALF; Grupo Gay da Bahia; MOLECA; Grupo Identidade de Campinas. Esse material começou a ser doado ao AEL entre a segunda metade da década de 1980 e o início dos anos 1990.

17 O Acervo Bajubá se iniciou em 2010, por iniciativa de um grupo de artivistas, artistas, colecionadores e pesquisadores LGBTQIA+. O seu objetivo é constituir um acervo voltado para a preservação, 
uma exposição de mesmo nome em 2017; o surgimento de iniciativas de investigação e reflexão sobre as experiências de pessoas LGBTQIA+ durante o período da ditadura civil-militar brasileira (1964-185), no marco das investigaçóes da CNV e das comissóes estaduais da verdade, entre 2014 e 2015, ou da atividades desenvolvidas pelo Memorial da Resistência de São Paulo; ${ }^{18}$ a difusão da produção de conteúdo digital voltado para o público LGBTQIA +, difundido em blogs, revistas digitais, sites, perfis de redes sociais, podcasts ou no YouTube, como o blog "Histórias e Memórias das Homossexualidades", produzido pela pesquisadora Rita Colaço. ${ }^{19}$

Nesse contexto mais amplo de processos políticos e culturais de emergência de memórias dissidentes que se inserem a fundação do MDS e suas iniciativas posteriores, como o "Memórias da Diversidade Sexual". Este programa dialoga com as iniciativas que citamos também devido aos critérios de seleçáo de quais experiências do passado são narradas e quais são silenciadas. Notamos que, de modo geral, as memórias que emergem desses processos enfatizam uma narrativa histórica sobre a trajetória das dissidência sexuais e de gênero centrada nos períodos da ditadura civil-militar e nos primeiros anos após a abertura política (décadas de 1960, 1970 e 1980). Este marco temporal reforça um "tempo intersubjetivo" que confere às narrativas pessoais visibilidade e reconhecimento ao colocá-las em relação a partir da contemporaneidade de influências, processos sociais, acontecimentos e rupturas subjetivas que marcaram as distintas histórias de vida, permitindo assim a sua escuta, seu uso e sua circulaçáo (Rago, 2013, p. 34-40). Por outro lado, atribui distintos níveis de legitimidade a quem narra com um ênfase posta nas experiências de homens gays cis e brancos, em detrimento de outras identidades que continuam invisibilizadas ${ }^{20}$-, e sobre o que se narra, em meio a processos de disputas de sentidos sobre o passado, particularmente, conflitos pela

salvaguarda e investigação historiográfica da arte, memória e cultura LGBTQIA+. Para tanto, voltouse para a aquisição de documentação em diversos suportes que tematizem a diversidade sexual e a pluralidade de expressões de gênero no Brasil. Sua coleção contabiliza cerca de 4.000 itens como obras de arte, periódicos, fotografias, audiovisuais, LPs, CDs, cartazes e camisetas de ativismo produzidos por pessoas LGBTQIA+ brasileiras, além de produções LGBTQIA+ estrangeiras traduzidas e que circularam pelo país. A partir de 2019, a Casa 1, casa de cultura e acolhimento LGBTQIA+, em São Paulo, tornou-se a sede do Bajubá. Disponível em: http://acervobajuba.com.br/. Acesso em: 9 fev. 2021.

O Memorial da Resistência de São Paulo já produziu eventos e materiais específicos sobre as experiências das pessoas LGBTQIA+ durante a ditadura militar. Entre 15 de outubro de 2020 e 26 de abril de 2021, esteve em cartaz a exposição "Orgulho e Resistências: LGBT na ditadura". A mostra, realizada em parceria com o MDS, trouxe um recorte sobre as relações entre o autoritarismo e a diversidade sexual e de gênero. Na página do projeto Instituto Temporário de Censura é possível encontrar o "Dossiê Orgulho e Resistências", um conjunto de textos e de materiais audiovisuais produzidos por meio de mediações realizadas pela Casa 1 e pelo Acervo Bajubá a partir da exposição. Ver: https:// institutotemporario.casaum.org/. Acesso em: 27 fev. 2021.

19 Disponível em: https://memoriamhb.blogspot.com/. Acesso em: 3 maio 2021.

20 Vale recordar a problemática escolha pelo termo "homossexualidades" como categoria utilizada nas discussões da CNV para se referir de modo total às sexualidades e identidades/expressões de gênero dissidentes à cisheteronormatividade. Baseado em um controverso posicionamento de que este 
visibilização e preservação de memórias LGBTQIA+, ameaçadas por lógicas políticas e culturais baseadas na valorização da cisheteronormatividade. ${ }^{21}$

Os episódios do programa "Memórias da Diversidade Sexual" disponibilizados no YouTube formam este "tempo intersubjetivo" a partir das escolhas feitas sobre quais trechos das entrevistas compóem os recortes temáticos abordados em cada um dos episódios. Essas escolhas reforçam, assim, um eixo narrativo em comum, no qual as histórias geralmente começam entre o final da década de 1940 e o início dos anos 1950, enfatizando as experiências nos primeiros espaços de sociabilidade (família, bairro, escola); seguem pelo final da década de 1950 e início da década de 1960, abordando experiências relativas aos processos migratórios e à modernização e ao desenvolvimento dos centros urbanos (Rio de Janeiro e, sobretudo, São Paulo), em paralelo à formação de espaços de efervescência cultural e de possibilidades de emergência de outras práticas de sociabilidade, sexuais e de afeto, que resultam no rompimento com padróes tradicionais de conduta e de alguns valores e códigos morais estabelecidos; enfatizam o período da ditadura, os impactos das transformaçôes bruscas fruto de um processo acelerado de modernizaçáo do país, a partir dos anos 1970, e as possibilidades de se produzir práticas sociais e culturais que escapassem ao enquadramento moral, à censura e à perseguiçáo; e concluem com os primeiros anos após a abertura política, tendo a epidemia do HIV/AIDS em meados da década de 1980 como um epílogo.

Podemos ainda perceber que, de modo geral, os episódios silenciam as experiências vividas entre os anos 1990 e os anos 2000, reforçando alguns marcos temporais a partir dos quais geralmente são produzidas as memórias dissidentes no Brasil, particularmente o período da ditadura civil-militar, o "desbunde" e os movimentos culturais da década de 1970 e início dos anos 1980, a perseguição policial às dissidências de gênero e sexualidade, as origens dos movimentos de afirmação homossexual e os efeitos da epidemia do HIV/AIDS.

Em relação à expectativa futura, devemos reconhecer a aposta política e cultural dessas narrativas ao observarmos, como afirma Maurício de Almeida Abreu, em diálogo com as teorias do historiador Jacque Le Goff e do filósofo Michel Foucault, que as instituiçóes de memória foram constituídos pelas classes dominantes (Le Goff), e que

era o entendimento hegemônico à época, os pesquisadores envolvidos com esse agenciamento de memória política afirmam que a travestilidade e a transgeneridade eram entendidas como formas de homossexualidade (Green; Quinalha, 2015, p. 11).

21 Segundo Caravaca Morera e Padilha (2017, p. 1306), a cisheteronormatividade seria: "[um] conceito que faz referência a um conjunto de relações de poder que normaliza, regulamenta, idealiza e institucionaliza o gênero, sexo e a sexualidade em uma linha ilógica e estritamente horizontal". Para pensar esse conceito, Vergueiro (2015, p. 59-60) parte da definição da cisgeneridade como: "um conceito composto pelas compreensões socioculturais ocidentais e ocidentalizadas de gênero tidas como naturais, normais e biológicas que são por sua vez as compreensões que fundamentam as leituras sobre vivências e corpos em termos de gênero". 
os arquivos seriam, portanto, expressóes de poder, ao expressarem também "o poder da sociedade sobre a memória e sobre o futuro" (Abreu, 1998, p. 86). Nesse sentido, a transmissáo das memórias de pessoas LGBTQIA+ pelos testemunhos pode conferir também visibilidade e reconhecimento, ao tentar superar um constante apagamento de suas vivências, influenciando as possibilidades de vivenciar sexualidade e gênero (Fraccaroli, 2019, p. 59) a partir desses encontros intertemporais, como afirmam Boyd e Ramirez (2012, p. 5): "Indeed, there is a tacit mutual responsibility for elders to sit, reflect, and recall while younger generations commit to recording, processing and analyzing the previous generations historical knowledge". 22

Frente a outros registros históricos que geralmente são preservados nos arquivos e que trazem um olhar do "outro" sobre o que é ser uma pessoa LGBTQIA+ discursos biomédicos, policiais, das agências estatais e da imprensa ${ }^{23}$-, a emergência de testemunhos de pessoas LGBTQIA+ permitem que elas reivindiquem o seu lugar de agência ao narrar suas próprias vidas para além do que a sociedade as imaginava capazes de viver e do que as desejava ver contando, como apontou Amara Moira, ao analisar a produção literária trans (Moira, 2021).

Ao assumir um lugar de agência na produção de suas memórias, esses indivíduos opóem-se a um lugar de vitimização no qual a sociedade os costuma colocar quando o espaço dado às histórias de pessoas LGBTQIA+ se resume à atenção dada aos relatos sobre discriminação, violência e marginalização social. Logo, ao contar suas próprias histórias ou ao participar de iniciativas coletivas de resgate e valorização das memórias LGBTQIA+, eles e elas colocam a ênfase na sua capacidade de ação e nas estratégias de sobrevivência, resistência e negociação, em meio a relações de poder (Arfuch, 2013, p. 96).

O resgate de experiências no passado de pessoas LGBTQIA+ permite ainda o seu uso político por geraçóes posteriores, como apontou Jaqueline Gomes de Jesus, em relação aos usos contemporâneos de Xica Manicongo, tornando-as "âncoras” de um "barco" em busca de cidadania - um "termo inseguro e assaz inconsistente, inalcançável há milênios para os grupos discriminados" - e do reconhecimento de suas subjetividades e suas formas de existência (Gomes de Jesus, 2019, p. 258-259).

Uma relação similar pode ser encontrada da leitura de abigail Campos Leal sobre "Os Corpos e a Polícia”, uma das seções da exposição "Orgulho e Resistência: LGBT

22 "De fato, há uma responsabilidade mútua tácita para os idosos sentarem, refletirem e recordarem, enquanto as gerações mais jovens se comprometem a registrar, processar e analisar o conhecimento das gerações anteriores" (tradução livre dos autores).

23 Sobre este aspecto, Simonetto (2018, p. 31) questiona: "Nos preguntamos si es posible pensar a los médicos, policías, periodistas o funcionarios como antropólogos. Proponemos analizar textos polifónicos marcados por la desigualdad de enunciación en los que nos aparece un código del que debemos de-construir su verdad para tomar los indicios que nos hablen de las vidas subalternas sumidas en su discurso". 
na Ditadura", publicada no site do "Instituto Temporário de Censura". Por meio de fotos encontradas no Arquivo Público do Estado de São Paulo, esta seção registrou as detençóes de gays, lésbicas e travestis durante as rondas realizadas pela polícia no centro de São Paulo durante a ditadura. Essas operaçôes tinham um objetivo de higienização moral, sendo aplicada sobre tipos sociais "indesejáveis", enquadrados na Lei de Vadiagem. No presente, algumas dessas fotos são os registros tanto da perseguição policial a esses corpos e do cerceamento das suas possibilidades de circular pela cidade, quanto da própria existência dessas figuras marginais. A leitura que abigail produz no presente destaca, para além do "registro das humilhaçôes, dos encarceramentos y das mortes levadas a cabo pelo Estado", uma "arte escura da vida":

O que escapa nesses olhares indecifráveis é o próprio controle, a norma, a ordenação colonial dos corpos, dos gestos, dos desejos, que não se fazem totais nem mesmo no momento, no registro exato da dor. [...] Porque um sorriso também pode esconder mais do que mostra. y e/u tento ouvir o que esses rostos calados cantam, murmuram. $\mathrm{O}$ abraço da camaradagem preta foi sempre testemunha de humilhaçôes racistas y transfóbicas, sempre soube que estavam atados, selados, não só nessa exposição, na ordenação dessa exposição, mas no próprio tecido da vida. e/u sinto ecoando em $\mathrm{m} / \mathrm{im}$ a fuga desses olhares, que apontam para desejos de vinganças trans pretas extravagantes, como quem diz: 'você me paga, seu disgraçado! Vocês vão ver! Todos vocês!'. (Campos Leal, 2021, p. 3).

Para abigail, o uso de um registro policial, de "um arquivamento das humilhaçóes e da dor", no presente abre a possibilidade de que a vida sobrevenha como "arquivo impossível”, estabelecendo uma genealogia entre as experiências de vidas de pessoas LGBTQIA+ do passado com as do presente: "essas foto-grafias inscrevem, no lugar mesmo da dor y da violência colonial, o intraduzível desejo de vida y de aboliçáo que as carcaças racializadas trans de ontem, de hoje de amanhá, emaranhadas anunciam" (Campos Leal, 2021, p. 3). Dessa forma, passado, presente e futuro se sobrepóem na produção de memórias dissidentes.

\section{"Tem ditadura para travesti?"}

O primeiro aspecto que buscaremos analisar nos testemunhos do programa "Memórias da Diversidade Sexual" é o espaço concedido e/ou agenciado nessas narrativas a partir de interpelaçôes sobre a visão e experiências desses agentes no marco da ditadura civil-militar brasileira (1964-1985). Esta escolha não é fortuita, pois este parece ser um eixo constantemente presente e indagado nas narrativas históricas e nas memórias de LGBTQIA+, o que certamente pode ser compreendido tanto como um 
efeito das discussões na CNV, quanto pelo recrudescimento conservador no Brasil.

Se a emergência desse campo instaurou um importante espaço para a reivindicação por reparação e direitos de cidadania por LGBTQIA+, além de fomentar outras narrativas e olhares sobre a ditadura civil-militar, é preciso certa cautela com alguns de seus enunciados e recortes, em especial, quando consideramos: a) produçóes historiográficas mais recentes, como a de Denise Rollemberg (2016), que questionam o binômio repressão-resistência e indagam uma "zona cinzenta", que tensionam tal binômio; b) a desigual partilha da participação e presença nessas narrativas, visto a ênfase na categoria "homossexualidades" escolhida inicialmente pelo campo, que fazem, por exemplo, Helena Vieira questionar ainda em 2015: "onde estavam as travestis durante a ditadura?"24

Esse último questionamento remete não apenas à presença das travestis na ditadura e em suas narrativas, mas também, como provoca Sissy Kelly ao ser perguntada por Joáo Nery sobre sua vida na ditadura: "Tem ditadura para travesti?" (Nery, 2019, p. 146). Entendemos que aquilo que a fala de Sissy busca retratar é a permanente continuidade das condiçóes sociais e políticas que negam a travestis e transexuais a possibilidade de habitar o humano (Bento, 2018), o que é questionado por Sissy e Helena.

Desse modo, frente a certo "essencialismo estratégico" (Spivak, 1985) que demarca o campo, é preciso reconhecer a desigualdade de posiçôes ocupadas por essas diferentes identidades ainda no presente, reconhecendo seus efeitos em termos de acesso ao poder de narrar o passado. Parece também adequado considerar as possibilidades de que esse agenciamento, focado nos arquivos do Estado (top-down), na violência e na discriminação, por vezes acabe por desconsiderar outros marcadores sociais da diferença, como raça e classe social, e conduzir esses agentes ao lugar de vítimas, desconsiderando outras possibilidades e acontecimentos ocorridos durante a ditadura. Nesse sentido, é muito acertada a observação de Carlos Fico no prefácio da obra de Green e Quinalha, ao afirmar que:

[...] não se deve reduzir a história do Brasil entre 1964 e 1985 à história da ditadura militar. É um simples jogo de palavras, mas com ele quero sustentar que náo podemos pensar o período simplesmente como tendo sido o palco de enfrentamento entre repressão e vítimas: na esfera do cotidiano, da vida privada,

24 Esse texto foi originalmente publicado na Revista Fórum, algumas semanas após o lançamento de "Ditadura e homossexualidades: repressão, resistência e a busca pela verdade", livro organizado por James Green e Renan Quinalha, que reuniu textos de pesquisadores envolvidos com as discussões na CNV e nas comissões estaduais da verdade. Recentemente, o texto de Vieira foi retirado da revista Fórum, mas uma versão ampliada pode ser consultada em Vieira e Fraccaroli (2018) e foi repostado no site Pragmatismo Político. Disponível em: https://www.pragmatismopolitico.com.br/2015/04/acaca-aos-homossexuais-e-travestis-na-ditadura-militar.html. Acesso em: 1 mar. 2021. Vale comentar também que esse questionamento deu origem à peça de teatro de mesmo nome, que estreou na $7 \mathrm{a}$ Mostra de Artes do Porto Iracema em 2019, na cidade de Fortaleza. 
das relaçóes interpessoais, muita coisa surpreendente aconteceu [...]. (Fico, 2015, p. 16).

Essa posição corre ainda o risco de eclipsar outras possibilidades de narrar a si mesmo para esses agentes, a partir de eixos que lhe façam mais sentidos e/ou que produzam outros lugares para si e para a comunidade LGBTQIA+, para além do espaço da vítima. De fato, essa ênfase, talvez até mesmo irrefletida, já se encontra presente na mensagem de abertura de todos os episódios do programa, que afirma:

Este programa tem como objetivo preservar a memória da comunidade LGBT brasileira através da coleta de testemunhos de pessoas pertencentes a essa população que contam suas histórias, relatam suas experiências de vida e a discriminaçáo que sofreram simplesmente por terem uma orientaçáo ou identidade discordante da maioria. (grifos nossos).

Fato é que a vivência de experiências de discriminação e de outras expressóes de violência motivadas pela LGBTQIA+fobia são e/ou foram presentes na vida dessas pessoas. Entretanto, que tal constataçáo signifique ou se desdobre em uma universalidade da experiência, pressupondo uma discriminaçáo una (note-se o "a discriminaçáo" da apresentaçáo), uma compreensão acrítica da ditadura e/ou que essas se constituam uma passagem necessária dos testemunhos, já nos parece algo problemático - como demonstra o testemunho de César Giobbi e Paulo Mortari.

Paulo Mortari nasceu em São Paulo, mas cresceu em Londrina, no Paraná. Aos 18 anos de idade, retornou para sua cidade de origem. Segundo conta, essa mudança facilitou para ele "assumir" a sua sexualidade, que no Paraná "era coisa não declarada". $\mathrm{Na}$ faculdade, Paulo viveu suas primeiras experiências sexuais que nesse momento foram "esporádicas". Aos 26 anos de idade, ele conheceu seu atual marido, César Giobbi, na greve dos jornalistas em Sáo Paulo, iniciada em maio de 1979, por melhores condiçóes salariais e imunidade dos representantes sindicais nas redaçóes (César Giobbi e Paulo Mortari, 2017).

César, por sua vez, nasceu na Itália, onde seu pai estava fazendo doutorado em Engenharia. Com um ano de idade, ele voltou para o Brasil e cresceu em São Paulo. Durante a adolescência, César define a sua vida amorosa como hétero e sua vida sexual como gay, pois, apesar de só ter namorado meninas, vivia relaçóes sexuais com meninos. César casou-se e esteve nessa relação heterossexual até não "aguentar" a "divisão de ser uma coisa de dia e outra quando dava para ser", o que o levou a separar-se e assumir sua sexualidade. Nessa época ele trabalhava no Jornal da Tarde, o que para ele ajudou muito, por estar em um meio de intelectuais que "não tinham nada contra ninguém".

Diferentemente de Paulo, César conta que acha que "transou com a cidade de Sáo Paulo" inteira. Em uma das assembleias da greve no Teatro do TUCA (Teatro da Universidade Católica de São Paulo), César se aproximou de Paulo e o convidou para 
ir a um show de Ney Matogrosso. Depois de um mês, Paulo se mudou para a casa de César e os dois nunca se separaram (César Giobbi e Paulo Mortari, 2017).

$\mathrm{O}$ que nos chama especialmente a atenção em ambos testemunhos é o reconhecimento de que apesar de episódios esporádicos de bullying durante a infância e a adolescência motivados por suas sexualidades dissidentes, o casal afirma que tais episódios não "atrapalharam suas vidas", "nem definiram suas escolhas" naquele momento. É curioso também observar que eles reconhecem esse momento positivamente como "um vendaval" de acontecimentos ("uma efervescência") e que tampouco concedem um espaço relevante para a ditadura em suas experiências de vida, aspectos que são abordados na quinta e última parte de sua entrevista, "Militância, política e cidadania", que se inicia com Paulo e César recordando suas experiências durante a ditadura:

[Paulo] - Vamos começar com a ditadura: eu não me lembro de absolutamente nada. Eu passei a época da ditadura fumando maconha. Então eu ficava na porta da escola, com uns amigos e não sentia nada disso em relação à política de homossexualidade [...] Não me lembro de nada. Absolutamente nada, em relação à ditadura e perseguição a gays. Porque nessa época tinha Dzi Croquettes a toda, tinha toda uma efervescência aí que não me lembro de ter essa relação.

[César] - Eu também senti como cidadão, não como gay.

[Paulo] - Sim...

[César] - Claro, como cidadão. Às vezes, eu tava dirigindo e tinha uma blitz, eu ficava apavorado. Eu não tinha nada a ver com nada. Mas eu ficava apavorado porque eu pensava: e se eles me confundirem com alguém, meu pai nunca me acha, eu vou acabar num desses poróes aí e ninguém nunca vai me achar. Eu ficava com medo. Eu tinha medo, medo. Não por ser gay.

[Paulo] - É, eu não me lembro de nada disso também.

[César] - Bastava você estar na rua.

[Paulo] - Zero...

[César] - Eu sentia essa insegurança, sim. Sentia. E não era porra louca, não. Mas a militância gay, acho que a gente nunca participou de nada. (César Giobbi e Paulo Mortari, 2017).

O medo como tônica geral da sociedade, experienciado por sujeitos dissidentes para além dos espaços de militância ou de sociabilidade dissidente, talvez mais dialoguem com a pecha de subversivo do que com a identidade "homossexual". Isso dialoga com o testemunho de "Bira", que afirma: "Então a pecha de 'subversivo', ela pairava sob a cabeça de todo mundo... [...] Porque como eu te falei, eu não era de ficar na rua, eu vou num lugar, entro lá dentro, tô lá dentro, saio e vou pra casa" (Ubirajara de None Caputo, 2018).

Nesse sentido, o "confundir com alguém" reportado por César se refere ao controle não apenas das sexualidades, expressóes e identidades de gênero dissidentes, 
mas também de orientações políticas subversivas e, como explica Morando, outros setores compreendidos como nocivos pela ideia em voga de degenerescência, que, segundo tal ideia, exporia o corpo social a potenciais riscos, sendo composta por subversivos, desviados, anormais, transviados, cabeludos, mulheres da vida, bêbados, usuários de drogas, entre outros (Morando, 2015, p. 56).

A ideia de "bastar você estar na rua" como sinônimo de riscos também demonstra esse traço amplamente compartilhado pela sociedade brasileira nesse momento de restrição dos espaços públicos. Na entrevista, relacionado a esse medo compartilhado por todos e ao controle de setores subversivos, César comenta que "Bastava você estar na rua", emendando que "Eu sentia essa insegurança, sim. [...] E não era porra louca, não" (César Giobbi e Paulo Mortari, 2017, grifos nossos) e afirmando que ele e Paulo militariam organizadamente apenas a partir do ano de 2005.

Essas últimas duas afirmaçôes são provocativas quando consideramos as principais referências do campo de pesquisas que articulam ditadura e sexualidades. De modo geral, elas demonstram a possibilidade de ser homossexual, sem ser porra louca - ou seja, subversivo -, mas ainda assim, sentir-se ameaçado pela violência da ditadura e/ ou limitado por ela. Esse conjunto de percepçóes, somadas às que lhe prosseguem, que entendem possibilidades de "militar" para além dos grupos de afirmação homossexual, compreendendo ainda que de controversos modos que o "pessoal é político", como ensinou a segunda onda do feminismo, deslocando um pouco a centralidade dessas narrativas de resistência e abordando também outros modos de resistir, ainda que de um modo que náo necessariamente resistente à ditadura em si, mas à heteronormatividade.

Essa percepção de uma militância posterior ao período em que normalmente tais agentes são indagados é capaz também de demonstrar suas possibilidades de agir para além desse período, ou seja, reconhecendo possibilidades de mudança no posicionamento político e outras significaçóes do passado a partir do presente, para além do distanciamento histórico.

Entretanto, as experiências de Paulo e César em muito contrastam com os relatos de Eloína dos Leopardos e de Lili Vargas, que apesar de compartilharem a condição de não terem participado dos grupos de militância organizada, táo enfatizados quando se aborda esse passado, sentiram o peso da ditadura de modo mais contundente em seus cotidianos. Dessa forma, seus relatos lançam luz sobre as diferentes exposiçóes à violência de cada categoria identitária, considerando também outros marcadores sociais da diferença.

Eloína dos Leopardos nasceu no Rio de Janeiro. No início dos anos 1960, aos 13 anos de idade, começou a frequentar a Praça Tiradentes, centro da cidade, onde conheceu os gays que trabalhavam com as vedetes. No ano seguinte, começou a trabalhar no teatro de revista, como camareira da atriz Nélia Paula. É nesse momento que ela conheceu na Cinelândia um grupo que se travestia e se unia para organizar concursos de miss escondidos, do qual participaram Rogéria, Jane Di Castro e Divina 
Valéria (Eloína dos Leopardos, 2017).

Em 1963, durante um baile de carnaval no Teatro República, o "Baile dos Enxutos", Eloína foi convidada para trabalhar no Teatro Rival com Sonia Mamede e Luz del Fuego. O início da ditadura, no ano seguinte, afetou o sucesso desse espetáculo. "Ninguém saía para vir ao teatro", conta Eloína, que sugeriu, então, a Américo Leal montar no Teatro Rival um show de travestis. A proposta resultou na realização de três espetáculos, mas, segundo Eloína, "sempre com certa coisa com a polícia". O seu relato traz em si a recordaçáo da presença da polícia na sua vida como transformista no Rio de Janeiro nos primeiros momentos da ditadura:

Eu encontrei o avô da Leandra Leal [Américo Leal] em Copacabana e falei para ele: por que você não faz um show de travesti ali. E ele me disse: 'Tá maluca, Eloína, como que eu vou botar travesti? A polícia não sai da Cinelândia. Eles tão querendo, quem manda agora é o Exército'. E era verdade, né. 'Mas por que você não tenta?'. Dois dias depois ele me procurou: 'Você consegue reunir um grupo pra fazer isso?'. Eu disse: 'Olha, minhas amigas estấo na Cinelândia', todas queriam se vestir de mulher, se vestiam, escondido e tudo. E tentamos fazer isso e deu muito certo. Chamava-se: 'Pode vir quente que eu estou fervendo', essa música do Erasmo Carlos. [...] Nós fizemos ali três espetáculos de grande sucesso, mas com essa certa coisa com a polícia. Tinha que lavar o rosto para ir para Copacabana. Não podia tomar uma lotaçấo. Não podia, apanhava. Eles botaram a gente dentro da delegacia, só saía dois dias depois. Ou um dia depois tinha que fazer faxina. Mas às vezes encontrava um delegado, um policial de bom coração. Sabia que aquilo ali... Nós necessitávamos trabalhar para comer no dia seguinte. (Eloína dos Leopardos, 2017).

Nesse trecho, mais do que a percepção de um impacto da ditadura mais direto em sua vida, é interessante observar a identificação de um papel que confunde o binômio repressão/resistência: a figura de policiais de bom coração, que suscitam possibilidades outras de posiçáo nesse jogo entre repressores e resistentes, que compreendiam "a necessidade delas de comer".

No caso de Lili Vargas, nascida em 1951 em uma família tradicional de Limeira, interior de Sáo Paulo, foi no final da década de 1960 que ela mudou-se para Sáo Paulo por causa do trabalho do pai e que, a partir de sua transição, percebe o impacto da ditadura em sua vida. Na terceira parte da sua entrevista, intitulada "Ditadura Militar x LGBTs", ela recordou a perseguição policial em alguns dos espaços de sociabilidade no final da ditadura:

Naquela época, era uma época de ditadura, que tava no final, então era uma coisa muito ruim. Eles... a viatura era preta e branca na época. Entáo, elas vinham com tudo, elas vinham com tudo. Então quando elas viam que era gay, elas desciam com tudo, três, quatro, já pegava pelo cabelo, jogava, náo importava se você era maior, 
menor, não importava isso. Para eles era limpar, porque a gente era marginal para eles, né. E aí levava. A gente ia pro 3o Distrito, ia pro, aqui no Parque Dom Pedro, [...] e no $4^{\circ}$ Distrito na Augusta, e jogava a gente lá, a gente ficava lá dois dias, no meio de todos. (Lili Vargas, 2017).

Se na introdução da obra "Ditadura e Homossexualidades - repressão, resistência e a busca da verdade", suscita-se a ideia dos espaços de sociabilidade dissidente como locais relativamente seguros para a classe média, a ponto de restringirem a militância política para certos setores, "que não poderiam imaginar algo melhor" (Green; Quinalha, 2015, p. 23), o que a fala de Lili aparenta explicitar é uma diferenciação nessa percepção de seguro, fazendo referência às diferenças de abordagem entre as polícias de Rio de Janeiro e São Paulo e também considerando as consequências do fato de "ser bem feminina":

E naquela época a gente era bem feminina, né, então a gente entrava na cela dos maladráo lá, aqueles caras tudo, mas eles respeitavam, você entendeu, nunca houve um estupro, uma agressão, uma coisa forçada, nunca. Mas aí com esse passar do tempo aí foi melhorando, porque você estava na rua, que nem muitas vezes aconteceu, você tava em grupinhos, 3, 4, tava na rua e vinham os meninos, os rapazes, percebiam que você era gay e vinha e te agrediam mesmo. Aí aquela situaçáo, ou você corre, consegue, tenta escapar, e nunca a gente podia chamar a polícia, nunca, porque a gente apanhava deles, e da polícia também, você entendeu, então era uma coisa terrível. Que nem no Rio de Janeiro, eles levavam, faziam aquelas açôes [...] e levavam todas para a Urca. Quantas que não jogavam lá pra baixo. Você entendeu, que, né, e quem se salvava que se salvava, né. Entendeu, e quantas que a gente nunca mais soube. Então era todo esse tipo...Agora aqui em São Paulo era mais suave, né. A polícia era mais suave. E tinha aquelas coisas, sabe, de um acertinho. Aquelas coisas que a gente sabe, né, que acontece. Mas de agressão violenta contra a gente, não. Mas eles batiam também, sim, batiam bastante quando pegavam a gente. O primeiro bar de São Paulo que era bar gay, onde todas nós conseguíamos se reunir escondidas praticamente foi ali no Largo do Arouche e se chamava De Você. (Lili Vargas, 2017).

Dessa urgência em se defender é que Lili compreende a união de travestis, compondo estratégicos modos de resistência frente à falta de direitos e visibilidade:

A gente se defendia uma ao outro com unhas e dentes, entendeu. Entáo isso é que nos proporcionava um tipo de segurança, entendeu. Porque a gente se protegia uma com as outras. Não tinha essa aí vai lá apanhar então dane-se, entendeu. [...] Apesar de todas dificuldades, a gente procurava sempre se defender, que nós não tínhamos quem nos defendesse, polícia, nada, nada, entendeu, leis, tudo isso. (Lili Vargas, 2017). 
Ainda pouco abordadas pelo campo que articula ditadura e sexualidades, essas açóes compóem um variado repertório de resistência náo apenas à ditadura, mas em um sentido político mais amplo: pelo direito de ser/estar como se deseja, ou simplesmente, pelo poder de existir. Soma-se a esse repertório de resistência, por exemplo, organizaçôes de eventos de miss, como o mencionado por Eloína. Seria possível negar o aspecto político dessas práticas e dos espaços que produziam?25 Como veremos na próxima seção, recorrentemente, são as frequências a esses espaços e a identificação com determinadas práticas os marcos mais relevantes para a composiçáo das narrativas de si.

\section{"Agora eu sou Lili Vargas"}

Além dos aspectos já analisados, o relato de Lili Vargas traz em si outra possibilidade de narrar-se para além do binômio repressáo/resistência, concedendo primazia às suas relaçóes com os espaços e as práticas de sociabilidade dissidentes, essenciais para a compreensão de sua própria identidade. ${ }^{26}$ Ao mudar-se de Limeira para São Paulo com sua família, Lili conta que morou inicialmente no bairro do Ipiranga, onde conheceu "as gays do bairro". Uma dessas amizades que, segundo Lili, já era "mais descolada", a convidou para "conhecer a cidade":

[...] aí eu conheci a cidade, ela me trouxe na época, era acho que 1969 para 70 mais ou menos isso. Então o uau, o auê era na Galeria Metrópole, um luxo, entendeu? Aquele jardim era tudo assim... a Galeria Metrópole onde todas ficavam, todas, todos os meninos, né, os gays. E naquela época havia [...] fanchonas, eram homens que gostavam de garotos. E garotos, naquela época era maioria, tudo garotấo, né, tudo meninão de $16,17,15$ anos, as gays bonitas, né, novinhas. E eles ficavam doidinhos, né. Iam lá para procurar cantar a gente. Aí a Galeria Metrópole tinha o jardim, a 25 de março, Barão de Itapetininga, a Sete de Abril, passavam automóveis, rodavam. Entáo chamava-se autorama. Autorama, por que? Porque naquela época os meninos mais velhos, que hoje em dia se chama michê, ficavam ali nas ruas para paquerar as pessoas de carro que iam lá para escolher os garotóes, né. (Lili Vargas, 2017).

Explicitando as dinâmicas das quais passa a participar, percebemos uma ênfase

25 Refletindo sobre esses aspectos, tendo em mente a necessidade de diferenciá-los de outras formas de ativismo, sem com isso incorrer em depreciações, é que Rita Colaço Rodrigues (2012) propõe o termo protoativismo.

26 Néstor Perlongher (1987), a partir de etnografia realizada no centro de São Paulo na década 1980, já observara em seus entrevistados o entrelaçamento dos níveis categorial (identidades) e o espacial. 
positiva no relato de Lili, atribuindo importância a esse processo de "descobrir a cidade", o que articula também sua identidade como imigrante na cidade, e às amizades e os círculos de sociabilidade que cria.

Lili expande esse eixo narrativo, ao comentar sua volta à cidade de São Paulo, após uma temporada em que morou na casa da avó no Rio de Janeiro. "Mais escoladinha", Lili conta que ela passou a frequentar os locais da vida noturna do centro de Sáo Paulo - até então, havia comentado apenas de sua presença em práticas de sociabilidade, que ocorriam na rua. Um dos locais importantes na trajetória de Lili foi a boate Dani, onde, segundo ela, começaram a surgir as primeiras travestis, cuja presença se expandiu para outros espaços da noite:

Aí nós começamos a frequentar esse Dani. [...] Aí veio o Medieval, que foi também um sucesso enorme, [...] aí o Val [Improviso] [...] E aí tinha os shows de caricata, muito caricata, não era drag, na época era caricata. E tinham as montadas que eu era uma das participantes, né. Que chegava a noite, o fim de semana, botava peruquinha, maquiagem, era a forma da gente, né, um vestidinho, saltinho, e ia fazer uma dublagem no palco. Escolhia a cantora e fazia as dublagens. E aí fazer shows todo fim de semana, né. E aí a gente fazia show no Val, tinha uma na Rua das Palmeiras também, que era da Renata, que era Studio 573 [...]. E tinha a Cassandra, a Velany, maravilhosa, que, da minha época, a gente fazia show juntas também. Mas aí elas eram mais avançadas, né. Eram mais para mulher mesmo, para travestis do que pra montagem, né. Então, quer dizer, aí foi essas coisas, de dia era garoto e de noite era uma menina, né. (Lili Vargas, 2017).

Essa passagem, no testemunho de Lili, serve como uma espécie de introdução que contextualiza suas primeiras experiências de "montaçáo". Habitué das casas noturnas, em companhia de suas amigas, Lili achava um luxo "as gays montadas", surgindo então seu desejo de se montar. Inicialmente em casa, Lili começou a se montar sozinha e ensaiar números de dublagem, para apresentar-se posteriormente em casas noturnas:

E aí eu fiz o primeiro show no Val Improviso lá embaixo no Largo do Arouche [...]. Aí eu comecei a fazer os shows. E ia para uma boate, ia para outra, ia lá para a Rua dos Palmeiras [...] Mas aí depois eu falei sabe cansei, né, foi só uma fase, e parei de fazer e continuei a frequentar como garoto mais e foi passando, né. Aí o tempo vai mudando, ele vai passando e a gente vai, as pessoas vão mudando, os amigos vão desaparecendo, vai vindo outros. [...] Aí foram surgindo boates melhores e a gente foi frequentando. Até que eu falei quer saber eu um dia não vou fazer mais essas montagens, fazia montagens só em festinhas, em festinhas de aniversário de amigos, a gente ia, se montava, fazia dublagens, aquelas coisas todas. Mas eu não fiz mais, tipo boates assim, né, da noite. (Lili Vargas, 2017).

Lili conta que se afastou da "cidade" e passou a ficar mais em casa e no seu bairro, 
até que voltou a frequentá-la. Nesse segundo momento, seu relato diferencia três fases, relacionadas aos espaços que ela costumava ir: a fase do Nostro Mundo, seguida pela Medieval e pelo Corintho. Lili observa uma gritante diferença de contexto com a abertura de boates como a Nostro Mondo e a Medieval e, posteriormente, a Corintho. Para além do glamour relatado e de festas homéricas, ela considera o ambiente social e político da cidade, que podemos localizar nas décadas de 1970 e 1980, como uma "situação mais avançada, muito mais gays na rua, muito mais liberal [...] Aí já estava uma época super mais tranquila, e sem a retenção, né, contra os gays, mas tinha, né, tinha" (Lili Vargas, 2017).

Nesse momento, Lili já percebe certo incômodo com seu visual masculino. "E sempre querendo, sempre me incomodando com meu visual masculino. Sempre. Sabe? E eu sempre fazia de uma forma para aparentar mais feminina do que eu era naturalmente. Eu sempre tive cara de garota, sempre, sempre.", relata. Lili foi novamente morar no Rio e quando voltou para Sáo Paulo, começou, nas suas palavras, a "querer se transformar":

Aí eu falei, não, eu já tô bem, a minha cabeça já tá bem, eu não tou, não tou satisfeito com meu visual masculino. E via todas que já tinham as maravilhosas, já tinham as travestis belíssimas, montadas, feiras, sabe? Eu falei não, eu quero, sabe, eu quero. Aí eu falei, eu vou começar a me preparar, né, para poder ter uma forma feminina vinte e quatro horas por dia. Porque esse negócio de dia ser garoto e a noite ser mulher não dá, não dá. Eu quero ficar 24 horas por dia. Eu quero sair, eu quero curtir, eu quero ser eu, eu quero me sentir feminina como eu sou por dentro. (Lili Vargas, 2017).

Mesmo em uma idade mais avançada, Lili passou a tomar hormônios e decidiu colocar silicone, na época que denominou como "o auge do silicone". Desde então, ela diz ter realizado procedimentos cirúrgicos com o intuito de "fazer correçóes", algo que a faz sentir-se melhor, em um processo que considera ainda em curso, reconhecendo estar longe do ponto em que almeja chegar.

Em síntese, na história de Lili, a qual foi narrada sobretudo por suas etapas nesse processo de transiçáo, escutamos significaçóes outras do contexto político no qual se insere, assim como uma maior relevância desses espaços, práticas e círculos de sociabilidade. A partir do agenciamento por outros caminhos, que poderiam surgir em interpelaçôes e/ou agenciamentos forçados, sua conclusão seria pouco ou nada compreensível: "Entáo eu tou feliz comigo mesmo agora. Agora eu me realizei, entendeu? Agora eu sou a Lili Vargas, sabe? Eu não sou o Edson e nem o Edinho. Então eu sou a Lili Vargas" (Lili Vargas, 2017). 


\section{“Envelhecer significa que eu não fiquei no meio do caminho"}

Marise Louvison nasceu em 1952 em Bernardino de Campinas, interior de São Paulo, e mudou-se para a capital no início dos anos 1960. Segundo conta, Marise "acha que já nasceu lésbica", mas lhe faltava "consciência social" para entender que "ela não era a única", "nem a primeira". Na adolescência, Marise encontrou referências culturais na literatura e começou a relacionar-se com garotas. Entre os 18 e os 20 anos, sua irmá descobriu que ela tinha uma namorada, o que a levou a contar para os seus pais. O amor recebido por sua família, segundo Marise, foi importante para que ela tivesse tranquilidade para viver sua vida "com honestidade" (Marise Louvison, 2017).

O relato de Marise é marcado por uma valorização de viver a sua sexualidade abertamente. "Eu sempre tive uma vida tranquila e assumida, o que me liberou muito espaço", relata. Esta "vida tranquila e assumida" incluiu uma sucessão de namoros e casamentos desde a década de 1970, assim como a sua circulação pela noite lésbica de São Paulo e de Brasília. Em relação à noite de São Paulo, Marise insiste na diversidade de opçôes, mesmo falando "do tempo da ditadura":

Nós tínhamos o Piolini, né, tinha o Planeta, o Ferro’s, uma porção de boates que tinha, ali atrás do Redondo tinha uma boate que daí você podia, entendeu? Ah, hoje eu quero ir pro inferno, né, aí, o Inferno de Dante, aí você ia pra lá. Então nós tínhamos muitas opçôes. Era bem movimentada a noite paulista. E eu insisto, eu estou falando do tempo da ditadura, né. [...] Um outro ponto, já que a gente está falando do circuito gay, era o Largo do Arouche, gente. O Largo do Arouche era uma celebridade para nós, porque, eu não sei se você sabe, uma série de barzinhos um do lado do outro com as mesas para fora, era como se fosse Paris [...]. E a noite era obrigatório [...] entáo a gente passava por lá, os meninos faziam questão de desfilar [...] e tinha o Caneca de Prata, tudo, então eles faziam questão de passar por lá, depois a gente sentava lá, você entendeu? Então nós tínhamos uma, as opçôes, então um dia lá que a gente ia primeiro para depois ir pra boate, outro dia era pro Ferro's, outro dia era no Planeta. (Marise Louvison, 2017).

Marise destaca nesse cenário a importância do Ferro's Bar e do seu entorno no bairro do Bixiga, sobretudo para a afirmação de identidades lésbicas, como discutimos no tópico anterior:

[O Ferro's] era um desfile de grupos diferenciados, né. Entáo entravam as caminhoneiras, elas entravam sempre em grupo, né, aí você já tinha que manter a distância, tal. Aí entrava as das motos, que já é um outro tipo. Entravam as executivas, de terno, é isso que eu tou te falando, de terno, gravata. [...] E depois tinha a turma dos estudantes, né, a turma da USP, que se vestia de outra forma. Eu tentava me inserir aí numa série de grupos, mas eu era, claro, do grupo mais careta, né. [...] Mas era bastante diversificado. (Marise Louvison, 2017). 
$\mathrm{Na}$ década de 1970, Marise Louvison passou em um concurso para a Polícia Militar Feminina, o que a fez participar do policiamento às travestis no Centro de São Paulo. Em seu relato, ela caracteriza a repressão às travestis como uma repressão mais moral do que política, "porque era uma coisa muito mais de higienização da cidade porque eram pontos, naquela época, pontos nobres”. Essa perseguição contrastava com a experiência pessoal de Marise que, apesar de ser policial, continuou frequentando os espaços de sociabilidade:

Nós ficávamos na boate o tempo inteiro, não tinha batida, entendeu? De forma alguma, na boate, para saber... Ao menos que fosse aquelas mais pesadas. [...] Eu nunca tive um problema de a minha família ter que me tirar da delegacia porque houve uma batida, qualquer coisa assim, entendeu? Então não existia essa repressão. Não existia repressão. (Marise Louvison, 2017).

Durante o período em que esteve na Polícia, Marise iniciou uma relação com uma tenente. Essa relação, para ela, foi o motivo do seu desligamento da corporação, apesar de terem alegado oficialmente que lhe "faltava vocação". Cinco anos depois, Marise mudou-se para Brasília após passar em um concurso dos Correios. Mas, apesar de trabalhar em um órgão estatal durante a ditadura, ela continuou vivendo sem esconder sua sexualidade:

[...] eu vou trabalhar no Correio, [...] nós ainda tamo no tempo da ditadura, eu vou trabalhar na área internacional, eu tenho generais como presidente, como diretores, tudo isso, e eu continuei assumida. E eu nunca sofri problema por isso. Porque eu sempre tive em mente que é muito melhor você contar, é claro 'Ah, ninguém precisa saber com quem eu durmo'. Não, ser lésbica não é só dormir. Eu tenho 24 horas de vida. Então, é extremamente importante você contar, você conviver do que você inventar uma mentira, que uma mentira vai gerando a outra. (Marise Louvison, 2017).

Tanto em São Paulo, como em Brasília, Marise teve a chance de fazer uma rede de amigos, em sua maioria gays, com os quais frequentava a noite. Porém, ao longo do seu relato, Marise fala da perda de uma série destes "amigos maravilhosos" "para a AIDS":

[...] assim como levou quase todo mundo meu aqui de São Paulo e isso é um momento da minha vida muito difícil, né. Muito difícil mesmo. Você não sabia mais pra quem rezar, pra quem cuidar, porque tinha uns que morriam pela doença, outros se suicidaram, outros eram assassinados, entáo eu perdi uma base assim quase de vinte amigos. Amigos mesmo, da gente sair, ir pra noite, nos divertirmos, todos muito jovens, né. Então é uma parte muito difícil. (Marise Louvison, 2017).

Quando eu volto pra Sáo Paulo, eu fico sem vínculo. Porque toda a minha turma 
morreu. Entendeu? Toda. Não sobrou ninguém da minha turma mesmo, da turma que descia. As mulheres casam e somem, né, então você não acha. Os meninos, aonde eu tinha mais referência, a AIDS levou, né. (Marise Louvison, 2017).

"Agora nós estamos diante de alguns que sobreviveram", pontua Marise, o que lhe gera atualmente outra preocupaçáo: o medo de que estes gays mais velhos "voltem para o armário" por causa da valorização da juventude e por não ter espaços próprios voltados para estes "sobreviventes":

[...] quem se livrou da AIDS e permaneceu, o meu grande medo é como o gay normalmente, o mundo gay ele tem por princípio, por, que o belo é o que é o valoroso, [...] e o velho é por princípio o feio, então eu, a minha grande preocupação é que todo esse pessoal esteja voltando para o armário, porque se ele fica viúvo, ou se ele tá sozinho por um ou outro motivo, ele acaba virando o tio, a tia, que vira tranqueira. Ou então o tio, a tia legal. E ele acaba tendo que voltar pro armário mesmo, né, exatamente por você não ter espaços voltados. (Marise Louvison, 2017).

Para exemplificar isso, Marise narra um episódio ocorrido quando ela foi ao cinema assistir ao filme Azul é a cor mais quente (2013), e percebeu o incômodo dos jovens presentes com suas possíveis reações frentes as cenas de nudez e sexo:

Sabe o que é você estar no cinema, assim tranquila, tal, eu tou na minha, e toda hora tem alguém virando pra trás [...] e rindo, e aquela coisa toda. E eu mesma tenho uma amiga jovem da UnB, lá de Brasília, que ela veio me contar que imagina que na sessáo dela tinha uma senhorinha e que todo mundo ficou preocupado com a senhorinha. Eu disse: bom, mas você, não passou pela sua cabeça que a senhorinha podia ser lésbica? 'Ah, não, não pode ser, aquela não é. Entendeu? [...] se eu saio com um amigo gay de mais idade, a tendência é todo mundo achar que é o vovô e a vovó que tão na rua, entendeu? Ninguém, ninguém imagina que são dois gays. (Marise Louvison, 2017).

Algo similar ocorreu quando ela foi numa festa gay no parque de diversóes HopiHari. Enquanto esperava um amigo seu ir na montanha-russa, Marise foi abordada por um grupo de garotos dizendo-lhe: "Oi, vovozinha. Como você está, vovozinha? Olha, vovozinha, nós queremos deixar você tranquila, não se preocupe, aqui não acontecerá nada demais". Marise conta que a sua resposta foi dar uma gargalhada, porque ela "ia ter que explicar muita coisa para eles”. Ela oferece então uma explicação e possíveis alternativas para situaçóes como esta em que ela e outras pessoas LGBTQIA+ mais velhas não são reconhecidas por seus pares mais jovens:

Mas é muito comum isso, né. [...] 'Nossa, o cara veio aqui para a boate e trouxe a 
avó junto', né. Porque o gay normalmente não aceita a velhice. E eu acho que seria interessante que eles internalizassem isso: eu vou envelhecer. Eu quero envelhecer, entâo a velhice também tem que estar. Entấo, eu acho, criação de espaços, uma série de coisas para que o gay idoso pudesse frequentar. Por que isso? Nós vivemos o tempo todo inteiro que a sociedade é preconceituosa, que nós vivemos com preconceito isso e aquilo. E aí você, no seu próprio meio, você encontra uma série de preconceitos, né. Então, eu acho que é conscientizar todo mundo [...] e também que não há mal nenhum, envelhecer é muito bom, significa que eu não fiquei no meio do caminho, né. É bom. (Marise Louvison, 2017).

Ao se referir a "não ficar no meio do caminho" como algo positivo e que deve ser celebrado, Marise se refere tanto aos que foram vítimas da AIDS, como aos "amigos que se suicidaram quando começaram a ficar velhos": "Entáo ele se suicida de medo da solidão, medo da rejeição, porque, mais principalmente, em função dessa dicotomia do feio e do bonito", aponta. Marisse significa o seu testemunho como uma oportunidade para deixar uma "mensagem de consciência" para os mais jovens sobre a "ligação do gay com o jovem ou com o novo":

Eu gosto dessa chance, dessa oportunidade, de falar um pouco sobre a vida porque eu gostaria principalmente de dizer para os jovens: olha, vocês não inventaram isso, tá? Vocês não criaram. Eu tou falando de, eu nasci em 52, o sacristão da minha igreja era uma sacristâ, e chamava Marise ainda por cima [...] quer dizer você tem muitas história [...] que os jovens precisam conhecer para eu poder ir ao cinema, eu fui assistir Azul é a cor mais quente, e os jovens não ficarem preocupados porque tem uma senhorinha ali sentada, [...] Eles entenderem que eu tou lá pelo mesmo interesse deles. (Marise Louvison, 2017).

Nas seis partes que compóem a entrevista de Marise, ela traça alguns eixos importantes para discutirmos as formas como as experiências de velhices LGBTQIA+ são significadas pelos próprios sujeitos. A primeira é o reconhecimento da epidemia da AIDS em suas trajetórias de vida e suas experiências geracionais. No relato de Marise, mesmo sem o HIV impactar diretamente o seu corpo, a experiência compartilhada da epidemia e dos seus efeitos devastadores com os "amigos maravilhosos" que ela perdeu torna-se um fator importante na maneira como ela rememora sua trajetória e organiza subjetivamente um percurso com eventos traumáticos, mas que culminam em uma percepção positiva da sua própria sexualidade: ela é uma das que sobreviveu, uma das que "náo ficou no meio do caminho" (Saggese, 2015, p. 53).

Para Marise, o fato dela ser uma sobrevivente faz com que ela tenha algo a contribuir com os seus pares mais jovens: compartilhar as suas memórias. Dessa forma, Marise ressignifica a experiência de velhice como um momento em que é possível reatualizar suas experiências passadas, inclusive as dolorosas, e criar novos horizontes, pois a sua história traz em si uma capacidade de superação de lógicas tanto no passado 
como no presente que produziram interditos para que ela pudesse viver a sua vida como uma mulher lésbica abertamente (Rago, 2013, p. 73).

Nesse sentido, um elemento forte no relato de Marise é o seu questionamento de representaçôes de juventude, beleza e visibilidade como obstáculos para pensar-se as intersecçóes entre velhice e sexualidade na experiência de uma mulher lésbica (Seffner; Duarte, 2015, p. 60). Fazer os jovens entenderem que ela está no mesmo cinema, no mesmo evento ou festa LGBTQIA+ que eles "porque tem o mesmo interesse" é uma estratégia utilizada por ela para que a velhice não resulte em um "retorno ao armário". Consequentemente, Marise tensiona algumas das representaçóes recorrentes que frisam nas experiências de envelhecimento entre pessoas LGBTQIA+ aspectos negativos como a melancolia, a solidão e a desvalorização erótica (Simôes, 2011). O resultado das suas escolhas narrativas é o reconhecimento do envelhecer como um sinal de resistência, de superação, de sobrevivência e de orgulho (Henning, 2017).

\section{Conclusão}

A consulta a acervos de História Oral pressupóe um inevitável trabalho de representaçấo: as entrevistas cobram sentido enquanto implicam necessariamente a presença de um outro que as consulta e que, tornando-as próprias, torne-as significantes (Bacci; Oberti; Skura, 2012, p. 34). Logo, da mesma maneira como arquivos não são espaços mortos, nem depósitos de papéis do passado que perderam seu sentido no presente, os arquivos orais não são o acúmulo de entrevistas prontas, fechadas, das quais outros sujeitos, além daquele que entrevistou, não possam se apropriar e encontrar em seu conteúdo a possibilidade de gerar novos questionamentos. Estes por sua vez produzem novos sentidos para as entrevistas, para além daqueles que pautaram inicialmente a sua produção e a sua circulação pública, e garantem a sua vitalidade (Tolentino, 2019).

No caso do programa "Memórias da Diversidade Sexual", que analisamos neste artigo, a sua produçấo se insere, de um lado, como parte de um processo mais amplo de emergência de memórias LGBTQIA+ no Brasil, e, de outro, relacionada às características da instituição em que foi produzida, o MDS, e às conexóes que ela estabelece entre memória e direitos humanos. Podemos perceber isso na mensagem de abertura de todos os vídeos, que pressupóem que os relatos ali coletados e editados trarão em si histórias de indivíduos que sofreram discriminação por ter uma identidade de gênero ou uma orientação sexual dissidente da maioria. Dessa forma, além do exercício de produção e de preservação de memórias, atribui aos testemunhos um valor de denúncia que, por sua vez, explicaria por si só a sua importância política e cultural. Entretanto, ao analisarmos esses testemunhos, partimos de um lugar de 
problematização de alguns sentidos comuns atribuídos às experiências dos sujeitos dissidentes durante a ditadura civil-militar brasileira, particularmente o binômio repressão/resistência. Dessa maneira, a nossa leitura desses testemunhos privilegiou a agência narrativa dos sujeitos/testemunhas em produzir outras formas de contar-se para além desses enquadramentos que, como apontamos, pautaram muitas das iniciativas de valorização e reconhecimento das memórias LGBTQIA+ no Brasil.

Quais foram então essas outras formas de contar-se reconhecidas? O questionamento do binômio repressão/resistência na ditadura; o reconhecimento da experiência histórica de mulheres trans e travestis; as relaçóes construídas entre espaços e práticas de sociabilidade e a produçáo de identidades; a valorização das velhices como momentos de agência desses sujeitos; são alguns dos eixos aqui analisados a partir das perguntas que fizemos para as entrevistas consultadas. De acordo às questóes que elencamos no princípio, propomos comentar brevemente com o conteúdo relatado sobre a experiência dos dissidentes na ditadura e as categorias identitárias operadas.

Em relação às identidades, como na fala de Lili Vargas, percebemos nas entrevistas uma variaçáo nos usos das categorias identitárias quando utilizados para se referir ao passado e ao presente e a fluidez destas nos processos de relatar. Lili não utiliza travesti ou transexual, por exemplo, para se identificar, utilizando no princípio de seu relato uma outra sigla já fora de uso, a GLS (referente a gays, lésbicas e simpatizantes): "Meu nome é Lili Vargas, tá? E no meio do GLS eu sou bem conhecida. E bem considerada também".

Dessas observaçóes, depreende-se a importância da escuta de suas memórias e o cuidado com a naturalização das categorias identitárias a partir das quais são interpeladas. Sem dúvidas, não devemos negar os jogos políticos da representação, tão centrais nas democracias ocidentais, conforme Butler (2015). Observaçáo que serve também para pensarmos as relaçóes dos sujeitos dissidentes com a ditadura. Longe de negar a importância política da inclusão da temática como modo de se discutir a ditadura e também demandar direitos no presente, é preciso considerar as diferenças na diferença; ou seja, considerar não apenas o que houve de diferença entre as vivências de pessoas heterossexuais em relação às pessoas dissidentes à cisheteronormatividade, mas também às diferenças dentro dessa própria diferença. Deve-se também considerar como a partir desses processos de encontros com o poder, em chave foucauldiana, a resistência não é mera reação, mas, sobretudo, espaço de criação e potência.

Por último, gostaríamos de destacar a entrevista de Marise, com a qual fechamos a nossa exposição, que aponta para uma outra questáo que aparentemente não parece ter pautado a produçáo desses testemunhos: a necessidade de reconhecimento das experiências de velhices entre pessoas LGBTQIA+ de modo a evitar que esses sujeitos sejam relegados a um lugar marginal, de invisibilidade, de "volta ao armário". Além disso, as memórias de Marise apontam para a relevância que a escuta de suas memórias pode ter nos processos de visibilidade: o reconhecimento da importância do seu testemunho 
para a comunidade da qual ela faz parte. Para além dos sentidos comuns que atribuem às geraçóes mais jovens uma suposta falta de memória, gostaríamos aqui de afirmar essa importância relacionando-a ao contexto político que vivemos no Brasil, no qual as existências de pessoas LGBTQIA+ são publicamente questionadas por argumentos que apontam elas como uma "moda passageira", logo, sem uma genealogia com experiências de outros sujeitos no passado, ou como resultado de uma crise de valores morais. Acreditamos entáo que a vitalidade de testemunhos como os do programa "Memórias da Diversidade Sexual" está também na sua possibilidade de combater tais lógicas de silenciamento e de esquecimento, assim como por trazer em si valores positivos atrelados às experiências individuais e coletivas de pessoas LGBTQIA+. Dessa forma, os testemunhos aqui analisados trazem em si o reconhecimento da agência de homens e mulheres que, ao narrar as suas trajetórias, não se limitam apenas ao relato das violências sofridas e se reconhecem como sujeitos de suas próprias histórias.

\section{Referências}

ABREU, Maurício de Almeida. Sobre a memória das cidades. Revista da Faculdades de Letras Geografia, Porto, v. 14, 1998. p. 77-97.

ANSARA, Soraia. Memória política, repressāo e Ditadura no Brasil. Curitiba: Juruá, 2009.

ARFUCH, Leonor. Memoria y autobiografia: exploraciones en los límites. Buenos Aires: Fondo de Cultura Económica, 2013.

BACCI, Cladia; OBERTI, Alejandra; SKURA, Susana. Testimonios en archivos: nuevas perspectivas. Historia Oral, v. 15, n. 2, 2012. p. 33-49.

BAPTISTA, Jean; BOITA, Tony. Memória e esquecimento LGBT nos museus, patrimônios e espaços de memória no Brasil. Revista do Centro de Pesquisa e Formaçāo, n. 5, set. 2017. Disponível em: https://www.sescsp.org.br/files/artigo/70a5e644/a393/463e/a32c/38a11c4c671c.pdf. Acesso em: 1 mar. 2021.

BENEVIDES, Bruna et al. Dossiê dos assassinatos e da violência contra travestis e transexuais brasileiras em 2020. São Paulo: Expressão Popular: ANTRA: IBTE, 2021. p. 77-97.

BENTO, Berenice. Necrobiopoder: quem pode habitar o Estado-naçáo?” Cadernos Pagu, Campinas, v. 53, 2018. Disponível em: http://www.scielo.br/pdf/cpa/n53/1809-4449cpa-18094449201800530005.pdf. Acesso em: 1 mar. 2021.

BOSI, Eclésia. O tempo vivo da memória: ensaios de Psicologia Social. São Paulo: Ateliê Editorial, 2013.

BOYD, Nan Alamilla; RAMÍREZ, Horacio N. Roque. Introduction: close encounters. In: BOYD, Nan Alamilla; RAMÍREZ, Horacio N. Roque (Org.). Bodies of evidence: the practice of queer oral history. New York: Oxford University Press, 2012. p. 1-22.

BUTLER, Judith. O parentesco é sempre tido como heterossexual? Cadernos Pagu, Campinas, 
n. 21, p. 219-160, 2003.

BUTLER, Judith. Problemas de gênero: feminismo e subversão da identidade. Rio de Janeiro: Civilização Brasileira, 2015.

BUTLER, Judith. Corpos em aliança e a politica das ruas: notas para uma teoria performativa de assembleia. Rio de Janeiro: Civilizaçáo Brasileira, 2018.

CAMPOS LEAL, abigail. A carcaça trans racializada e a vida. São Paulo: Instituto Temporário de Censura, 2021. Disponível em: https:/www.casaum.org/carcacatrans_abigail.pdf Acesso em: 28 fev. 2021.

CARNEIRO, Ailton José dos Santos. Homossexuais em trânsito: representaçóes, militância e organização política homossexual na Bahia, 1978-1988. Dissertação (Mestrado em História Social) - UFBA, Faculdade de Filosofia e Ciências Humanas, Salvador, BA, 2017.

FACCHINI, Regina. Sopa de letrinhas? Movimento homossexual e produção de identidades coletivas nos anos 90. Rio de Janeiro: Garamond, 2005.

FACCHINI, Regina. Entre compassos e descompassos: um olhar para o "campo" e para a "arena" do movimento LGBT brasileiro. Bagoas, Natal, v. 3, n. 4, p. 131-158, 2012.

FACCHINI, Regina; SIMÓES, Júlio Assis. Na trilha do arco-iris: do movimento homossexual ao LGBT. São Paulo: Fundação Perseu Abramo, 2009.

FICO, Carlos. Prefácio. In: GREEN, James N.; QUINALHA, Renan (Org.). Ditadura e homossexualidades: repressão, resistência e a busca da verdade. São Carlos: EdUFSCar, 2015. p. 13-16.

FRACCAROLI, Yuri. Era um olhar e pronto: memórias do homoerotismo em São Paulo. Dissertação (Mestrado em Psicologia Social) - USP, São Paulo, SP, 2019.

GREEN, James N.; QUINALHA, Renan. Ditadura e homossexualidades. repressão, resistência e a busca de verdade. São Carlos: EDUFSCar, 2015.

GOMES DE JESUS, Jacqueline. Xica Manicongo: a transgeneridade toma a palavra. Redac, v. 3, n. 1, p. 250-260, jan./abr. 2019.

GONÇALVES FILHO, José M. Problemas de método em Psicologia Social: algumas notas sobre a humilhação política e o pesquisador participante. In: BOCK, Ana M. Bahia (Org.). Psicologia e compromisso social. São Paulo: Cortez, 2003. p. 193-239

GOLDENBERG, Mirian. A bela velhice. Rio de Janeiro: Record, 2013.

GOLDENBERG, Mirian. A invenção de uma bela velhice: de uma vida com mais liberdade e felicidade Revista Brasileira de Geriatria e Gerontologia, Rio de Janeiro, v. 21, n. 5, p. 529-53, 2018.

HARAWAY, Donna. Saberes localizados: a questão da ciência para o feminismo e o privilégio da perspectiva parcial. Cadernos Pagu, Campinas n. 5, p. 7-42, 1995.

HENNING, Carlos Eduardo. Na minha época não tinha escapatória: teleologias, temporalidades e heteronormatividade. Cadernos Pagu, Campinas, n. 46, p. 341-371, 2016.

HENNING, Carlos Eduardo. Gerontologia LGBT: velhice, gênero, sexualidade e a constituição 
dos “idosos LGBT". Horizontes Antropológicos, Porto Alegre, ano 23, v. 47, p. 283-323. 2017.

JELIN, Elizabeth. La lucha por el pasado: cómo construimos la memoria social. Buenos Aires: Siglo XXI Editores, 2017.

LIFSCHITZ, Javier Alejandro. Os agenciamentos da memória política na América Latina. Revista Brasileira de Ciências Sociais, São Paulo, v. 29, n. 85, p. 145-158, 2014. Disponível em: http://www.scielo.br/pdf/rbcsoc/v29n85/10.pdf. Acesso em: 1 mar. 2021.

MOIRA, Amara. Amara Moira: inventando Histórias. O Povo +, 23 mar. 2021. Disponível em: https://mais.opovo.com.br/reportagensexclusivas/2020/01/28/amara-moira--inventandohistorias.html. Acesso em: 2 maio 2021.

MORANDO, Luiz. Por baixo dos panos: repressão a gays e travestis em Belo Horizonte (19631969). In: GREEN, James N.; QUINALHA, Renan (Org.). Ditadura e homossexualidades: repressão, resistência e a busca da verdade. São Carlos: EdUFSCar, 2015, p. 53-82.

MORERA, Jaime Alonso Caravaca; PADILHA, Maria Itayra. Representaçóes sociais do sexo e gênero entre pessoas trans. Revista Brasileira de Enfermagem, Brasília, v. 70, n. 6, p. 1235 1243, 2017. Disponível em: http://www.scielo.br/scielo.php?script=sci_arttext\&pid=S003471672017000601235\&lng=en\&nrm=iso. Acesso em: 2 mar. 2021.

MOTT, Luiz (Ed.). Boletim do Grupo Gay da Bahia. Salvador: GGB/Secretaria Estadual de Justiça e Direitos Humanos, 2011. Disponível em: https://grupogaydabahia.files.wordpress. com/2018/02/2-boletim-do-ggb.pdf. Acesso em: 6 jun. 2021.

NERY, João W. Velhice transviada: memórias e reflexôes. Rio de Janeiro: Companhia das Letras, 2019.

PASSAMANI, Guilherme Rodrigues. Batalha de confete no "Mar de Xarayés": condutas homossexuais, envelhecimento e regimes de visibilidade. Tese (Doutorado em Ciências Sociais) - Unicamp, Campinas, SP, 2015.

PERLONGHER, Néstor O. O negócio do michê: prostituição viril em São Paulo. São Paulo: Editora Brasiliense, 1987.

POLLAK, Michel. Memória, esquecimento, silêncio. Estudos Históricos, Rio de Janeiro, v. 2, n. 3, p. 3-15, 1989.

POLLAK, Michael; HEINICH, Natalie. El testimonio. In: POLLAK, Michael. Memoria, olvido, silencio: la producción social de identidades frente a situaciones límite. La Plata: Ediciones Al Margen, 2006. p. 53-112.

RAGO, Margareth. A aventura de contar-se: feminismos, escrita de si e invençôes de subjetividade. Campinas: Editora da Unicamp, 2013.

RICH, Adrienne. Heterossexualidade compulsória e existência lésbica. Bagoas, Natal, n. 4, v. 5, p. 17-44, 2012.

RICOEUR, Paul. A memória, a história, o esquecimento. Campinas: Editora da Unicamp, 2007.

RIVERS, Daniel. Queer family stories: learning from oral histories with lesbian mothers and gay fathers from the pre-Stonewall era. In: BOYD, Nan Alamilla; RAMÍREZ, Horacio N. Roque (Org.). Bodies of evidence: the practice of queer oral history. New York: Oxford University Press, 2012. 
ROBIN, Régine. A memória saturada. Campinas: Editora Unicamp, 2016.

RODRIGUES, Rita de Cássia Colaço. De Daniele a Chrysostomo: quando travestis, bonecas e homossexuais entram em cena. Tese (Doutorado em História Social) - UFF, Niterói, RJ, 2012.

ROLLEMBERG, Denise. Resistência: memória da ocupação nazista na França e na Itália. São Paulo: Alameda, 2016.

ROUSSO, Henry. A memória não é mais o que era. In: AMADO, Janaina; FERREIRA, Marieta de Moraes (Org.) Usos \& abusos da História Oral. Rio de Janeiro: Editora FGV, 2006. p. 93-101.

SAGGESE, Gustavo Santa Roza. De afetos, diferenças e superaçóes: Aids, subjetividades e transformação social entre homens homossexuais em São Paulo. Bagoas, Natal, v. 9, n. 13, p. 31-56, 2015.

SEFFNER, Fernando; DUARTE, Gustavo. E quando não há muito mais o que guardar no armário? Homossexualidades e processos de envelhecimento. Bagoas, Natal, v. 9, n. 13, p. 57-82, 2015.

SILVA, Alessandro Soares. Por um Lugar ao Sol: construindo a memória política da homossexualidade (ou: Homossexualidade: uma história dos vencidos?!). Bagoas, Natal, v. 6, n. 8, p. 77-102, 2013.

STERN, Steve J. Battling for hearts and minds: memory struggles in Pinochet's Chile, 19731988. Durham, Carolina do Norte: Duke University Press, 2006.

SIMÓES, Júlio Assis. Corpo e sexualidade nas experiências de envelhecimento de homens gays em São Paulo. A Terceira Idade, São Paulo, v. 22, n. 51, p. 7-19, 2011.

SIMONETTO, Patricio. Intimidades disidentes. Intersecciones en las experiencias de homosexuales y lesbianas en Buenos Aires durante los sesenta y setenta. Transhumante, Antioquia, n. 11, p. 28-50, 2018.

SPIVAK, Gayatri Chakravorty. Interview with Angela McRobbie. Block, v. 10, p. 5-9, 1985.

TOLENTINO, Marcos. Arquivo, testemunhos e direitos humanos: o Arquivo Oral do Memoria Abierta. História Oral, v. 22, n. 1, jan./jun. 2019.

TORRES, Lilian de Lucca; DEBERT, Guita Grin. Entrevista com Guita Grin Debert. Ponto Urbe, São Paulo, n. 8, p. 1-10, 2011.

VERGUEIRO, Viviane. Por inflexöes decoloniais de corpos e identidades de gênero inconformes: uma análise autoetnográfica da cisgeneridade como normatividade. Dissertação (Mestrado em Cultura e Sociedade) - UFBA, Salvador, BA, 2015.

VIEIRA, Helena; FRACCAROLI, Yuri. Violências e dissidências: um breve olhar às experiências de repressão e resistência das travestis durante a ditadura militar e os primeiros anos da democracia. In: GREEN, James N.; CAETANO, Marcio; FERNANDES, Marisa; QUINALHA, Renan (Org.). História do Movimento LGBT no Brasil. São Paulo: Alameda, 2018. p. 357-378. 


\section{Fontes orais}

CAPUTO, Ubirajara de None (Bira). [dez. 2018]. Entrevistador: Yuri Fraccaroli. São Paulo, SP, 11 dez. 2018.

GIOBBI, César; MORTARI, Paulo. [2017]. Entrevistador: Luffe Steffen. Sáo Paulo, SP, 2017. Depoimento concedido ao programa "Memórias da Diversidade Sexual" do Museu da Diversidade Sexual de São Paulo. Disponível em: https://www.youtube.com/watch?v=pZEg2bXyMl4\&ab_ channel=MuseudaDiversidadeSexualMuseudaDiversidadeSexual. Acesso em: 6 jun. 2021.

LEOPARDOS, Eloína dos. [2017]. Entrevistador: Luffe Steffen. São Paulo, SP, 2017. Depoimento concedido ao programa "Memórias da Diversidade Sexual" do Museu da Diversidade Sexual de São Paulo. Disponível em: https://www.youtube.com/watch?v=rJse9xhe5Po\&ab_ channel=MuseudaDiversidadeSexual. Acesso em: 6 jun. 2021.

LOUVISON, Marise. [2017]. Entrevistador: Luffe Steffen. São Paulo, SP, 2017. Depoimento concedido ao programa "Memórias da Diversidade Sexual" do Museu da Diversidade Sexual de São Paulo. Disponível em: https://www.youtube.com/watch?v=P67VRvNeG9E\&ab_ channel=MuseudaDiversidadeSexual. Acesso em: 6 jun. 2021.

VARGAS, Lili. [2017]. Entrevistador: Luffe Steffen. Sáo Paulo, SP, 2017. Depoimento concedido ao programa "Memórias da Diversidade Sexual" do Museu da Diversidade Sexual de Sáo Paulo. Disponível em: https://www.youtube.com/watch?v=FtQIpGhCVzk\&ab_ channel=MuseudaDiversidadeSexualMuseudaDiversidadeSexual. Acesso em: 6 jun. 2021.

Recebido em 02/03/2021.

Versão final reapresentada em 05/05/2021.

Aprovado em 06/05/2021.

Contribuiçóes dos autores: Tolentino: concepção da pesquisa, pesquisa bibliográfica, seleção e escuta dos testemunhos, redaçẫo; Fraccaroli: concepção da pesquisa, pesquisa bibliográfica, seleção e escuta dos testemunhos, redação.

Fonte de financiamento: nada a declarar.

Conflitos de interesse: nada a declarar. 